\title{
Gıda Kaynaklı İmmünomodülatörler
}

\author{
Nutritional Immunomodulators
}

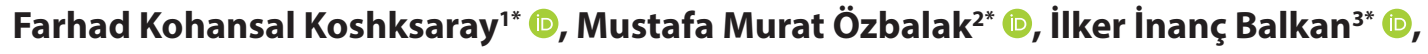 \\ Gaye Erten Yurdagül ${ }^{*}$
}

\begin{abstract}
1İstanbul Üniversitesi, Aziz Sancar Deneysel Tıp Araştırma Enstitüsü, İmmünoloji Anabilim Dalı, İstanbul, Türkiye ${ }^{2}$ Istanbul Üniversitesi, İstanbul Tıp Fakültesi, İç Hastalıkları Anabilim Dalı, Hematoloji Bilim Dalı, İstanbul, Türkiye

${ }^{3}$ Istanbul Üniversitesi-Cerrahpaşa, Cerrahpaşa Tıp Fakültesi, Enfeksiyon Hastalıkları ve Klinik Mikrobiyoloji Anabilim Dalı, İstanbul, Türkiye
\end{abstract}

*: Tüm yazarlar, isim sırasından bağımsız, makalenin yazımı ve hazırlanmasına eşit katkıda bulunmuştur.

ORCID ID: F.K.K. 0000-0003-2700-9534; M.M.Ö. 0000-0002-3040-4052; I.I.B. 0000-0002-8977-5931; G.E.Y. 0000-0002-5784-7785

Cite this article as: Koshksaray FK, Özbalak MM, Balkan II, Erten Yurdagül G. Gıda kaynaklı immünomodülatörler. Experimed 2020; $10(2)$ : 97-111.

\section{öz}

“Gıdanız ilacınız, ilacınız gıdanız olsun aforizması beslenmenin tıptaki merkezi rolüne atıfta bulunur. Patogenezi son yıllarda anlaşılan bir çok hastalığın beslenme ve mikrobiyota ile ilişkisinin çarpıcı şekilde ortaya konması ile adeta bir "beslenme rönesansı"nın kapısı aralanmıştır. İnsan, bir kez daha; "yediğinden ibaret"tir. Gıdalar; bağırsak bağışıklık sisteminin oral tolerans, salgısal IgA, lokal lenfoid odaklar, regülatör hücresel immünite ve kommensal mikrobiyomun çeşitliliği gibi kendine özgü özellikleri ile bütünleşebildikleri ölçüde "fonksiyonel" hale gelmektedir. Doğru seçilmiş probiyotik, prebiyotik ve sinbiyotikler ile güçlü immünomodülatör etkiler elde edilebilmektedir. Hayvansal proteinler ve bitki kaynaklı peptidlerin de immünomodülatör etkileri bulunmaktadır. Yatan hastalarda buğday proteini (gluten) kaynaklı glutamin takviyesi yapıldığında nozokomiyal enfeksiyon oranlarında ve mekanik ventilasyon gereken gün sayısında düşüş sağlandığı görülmüştür. Vitaminlerden; A vitamininin mukozal epitelyal bütünlüğün korunması ve enfeksiyon etkenlerine karşı güçlü nötrofil yanıtında önemli katkıları vardır. B12 vitamini güçlü immünomodülatör etki göstermekte, özellikle CD8 ${ }^{+}$T lenfosit sayılarında ve NK hücre aktivitesinde artışa katkıda bulunmaktadır. Vitamin C önemli bir antioksidandır. D vitamini, hücre proliferasyon ve diferansiyasyonunu uyararak doğal immün yanıtı güçlendirmektedir. Mutfağımızda yer bulan zerdeçal, sarımsak, havuç, patlıcan, kivi, bal gibi pek çok gıda ve gıda bileşeninin gerek doğal gerekse edinsel bağışıklık üzerindeki düzenleyici etkileri; anti-kanser, anti-enflamatuvar, anti-oksidan beslenme kürlerine dayanak oluşturmakta; gıdamız ilacımız olmaya devam etmektedir.

Anahtar Kelimeler: Gıda, immünomodülatör, probiyotik, prebiyotik, vitamin, mineral

\begin{abstract}
"Let food be thy medicine and let medicine be thy food." This aphorism refers to the pivotal role played by nutrition in medicine. The door of a "nutrition renaissance" has been opened with the striking disclosure of the relationship between nutrition and microbiota in the pathogenesis of many diseases, which has been better understood in the recent years. A person, once again, is "what he/ she eats." Foods become "functional" after their integration into the unique features of the intestinal immune system, such as oral tolerance, secretory Immunoglobulin A, local lymphoid foci, regulator cellular immunity, and diversity of commensal microbiome. It is possible to achieve strong immunomodulatory effects through an appropriate selection of probiotics, prebiotics, and synbiotics. Animal proteins and plant-derived peptides also exert immunomodulatory effects. It has been reported that the use of glutamine supplements from wheat protein (gluten) in patients helps in lowering the nosocomial infection rate and the duration of mechanical ventilation. Vitamin A contributes immensely in maintaining the mucosal epithelial integrity and aids in strengthening the neutrophil response to infectious agents. Vitamin B12 has a strong immunomodulatory effect and facilitates the increase in CD8 ${ }^{+}$T lymphocyte count and natural killer cell activity. Vitamin $C$ has well-defined antioxidant efficacy. Vitamin D strengthens the innate immune response by stimulating cell proliferation and differentiation. The regulatory effects of many foods and food ingredients such as turmeric, garlic, carrot, eggplant, kiwi, and honey in our kitchen on both innate and adaptive immunity serve as the foundation for anticancer, anti-inflammatory, and antioxidant nutrition therapies. Thus, our food continues to be our medicine.
\end{abstract}

Keywords: Food, immunomodulator, probiotic, vitamin, mineral 


\section{GíRiş}

“Gıdanız ilacınız, ilacınız gıdanız olsun (Let food be thy medicine and let medicine be thy food.)". Hipokrat (MÖ 400)'a atfedilen bu aforizmanın ona veya takipçilerine ait olup olmadığı kesin değildir. Ancak kesin olan şudur ki beslenme, tarih boyunca koruyucu ve tedavi edici tıbbın merkezinde yer almıştır (1). Modern farmakolojinin hızı ilerleyişi ile tedavi edici tıpta gıdaların önemi ikinci planda kalmış olsa da son yıllarda patogenezi anlaşılan birçok hastalığın beslenme ve mikrobiyota ile ilişkisi çarpıcı şekilde ortaya konmuş, adeta bir "beslenme rönesansı"nın kapısı aralanmıştır. Insan, bir kez daha; "yediğinden ibaret"tir.

Sağlığın korunmasında aktif ve dengeli çalışan bağışıkık sistemi son derece önemlidir. Bağışıklığın dengede tutulması için ilaca gerek duymaksızın günlük beslenme içinde yer verilen ve vücutta bazı biyoaktif bileşenler yoluyla bağışıklık fonksiyonlarını düzenleyici etki gösteren gıdalara "fonksiyonel gıda" adı verilmektedir. Meyveler, sebzeler, tahıllar, et, balık, süt ürünleri gibi tüm gıda kategorilerinin hepsi fonksiyonel gıda içerir (2).

Hastalıkların etiyolojilerinin genetik, epigenetik ve diğer etmenlerle kişiden kişiye değiştiği gittikçe daha açık hale gelmektedir. Farklı gıda bileşenlerinin ve egzersizin farklı kişilerin bağışıklık sistemi üzerinde farklı özgül etkiler oluşturduğu söylenebilir (3). Bu bileşenlerin bazıları bağışıklık tepkilerini artırıp enfeksiyona karşı yanıta katkıda bulunurken, bazıları düzenleyici etki ile alerji ve iltihabı baskılar. Fonksiyonel gıda bileşenlerinin bağışıklık sistemi üzerindeki etkilerine bağırsak bağışıklık sistemi ve mikrobiyotası aracılık etmektedir.

Bu derlemede, probiyotikler, prebiyotikler, proteinler, peptitler, vitaminler, mineraller dahil olmak üzere çeşitli fonksiyonel gıda bileşenlerinin immünomodülatör etkilerini özetlemeyi amaçladık.

\section{BAĞIRSAK BAĞIŞIKLIK SISTEMI}

Vücudun en büyük ve en dinamik immünolojik ekosistemi bağırsakta bulunur. Bağırsak bağışıklık sistemi bağırsakla ilişkili lenfoid doku (GALT) ve diğer hücrelerden oluşmaktadır (4). Ince bağırsakta, özellikle ileumda, villus ile kaplı mukoza epitel hücrelerinin altında, lamina propria içine yerleştirilmiş "Peyer plakları" adı verilen sekonder lenfoid yapılar vardır. Peyer plaklarında, dalak ve lenf düğümlerinde olduğu gibi B hücrelerinden zengin lenfoid foliküller, daha az oranda $\mathrm{CD} 4^{+} \mathrm{T}$ hücreleri, dendritik hücre ve makrofaj bulunmaktadır. Plazma hücreleri ve bellek $B$ hücreleri tarafından antikor üretimi bu bölgede gerçekleştirilmektedir. Peyer plaklarının üzerini mikrovillileri olmayan M (membranöz) hücreleri örter. M hücreleri pinositik aktivite ile bağırsak lümenindeki antijenleri lenfoid foliküllere iletir (5). Bağırsakta sadece patojenik bakterilerden değil, aynı zamanda gıda ve komensal bakterilerden de çeşitli antijenler vardır. Bağırsak bağışıkıı sisteminin bazı ayırt edici özellikleri bulunmaktadır:

1) Oral Tolerans: Protein yapıda antijenin ağızdan alınması halinde mukozal immün sistemde bulunan T hücrelerin aktive olmak yerine antijeni kabullenip yanıtsız (anerjik) kalmasıdır (6). Gıda alerjisinin bu mekanizma ile engellendiği kabul edilir. Oral tolerans, antijene özgü T hücrelerinin klonal delesyonu ve

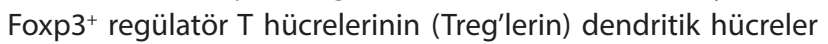
tarafından indüksiyonu ile ortaya çıkmaktadır (7).

2) Salgısal $\lg A(s \operatorname{g} A): \lg A$, bağırsakta en çok üretilen immünoglobülindir. IgA'nın salgısal bileşeni, immünoglobülinin bağırsak lümeninde proteolitik enzimler tarafından parçalanmasını engeller. Böylece, slgA patojen mikroorganizma ve toksinlerin yayılmasını, invazyonunu önler, bağırsak mikrobiyotasını kontrol eder. Bağırsak dendritik hücreleri IL-6, retinaldehid dehidrojenaz (RALDH) ve nitrik oksit (NO) üreterek (8), bağırsak epitel hücreleri ise IL-6 ve TGF- $\beta$ üreterek IgA izotipinin sürekliliğine katkıda bulunur (9).

3) Bağırsak mikrobiyotası: Insanlarda ve diğer memelilerde, doğumdan kısa süre sonra, özellikle vajinal doğum ve emzirme sürecinin katkısı ile, başlangıçta steril kabul edilen bağırsak lümeninde simbiyotik bakteriler çoğalmaya başlayarak bağırsak florasını oluşturur. İnsan bağırsağında yaklaşık bin türden, yüzlerce trilyon bakteri bulunur. Yaklaşık 60 trilyon somatik hücreden oluşan insan vücudu, bu sayıdan çok daha fazla'kendinden olmayan' bakteri hücresine ev sahipliği yapmaktadır. Firmicutes, Bacteroidetes, Actinobacteria ve Proteobacteria'nın baskın olduğu bakteri florasının hacmi ve bileşimi, anne sütü ve diyet gibi faktörlerden güçlü şekilde etkilenmektedir (10). Birçok çalışma, bağırsak simbiyotik bakterilerinin aslında misafir değil ev sahibi olduğunu, GALT dahil bağırsak dokusunun oluşumunda önemli rollere sahip olduğunu göstermiştir. Örneğin, bağırsağında simbiyotik bakteri bulunmayan (germ-free) farelerde, Peyer plaklarının sayı ve boyutunun diğer (normal) farelerden küçük olduğu belirlenmiştir. Dahası, salgısal IgA üretimi, normal farelere kıyasla germ-free farelerde genellikle daha düşüktür (11). Ayrıca, oral tolerans mekanizması da yine germ-free farelerde normal farelere göre daha düşük seviyede uyarılabilmektedir (12).

\section{1) PROBIYOTIKLERIN IMMÜNOMODÜLATÖR ETKILERi}

Dünya Sağlık Örgütü'ne göre probiyotikler; "oral yoldan yeterli miktarda alındığında sağlığa faydalı etkileri olan canlı mikroorganizmalar" dır. Alerjik hastalık, kolit, romatoid artrit, kolorektal kanser, çeşitli enflamatuvar hastalıklar, depresyon, anksiyete gibi birbirinden farklı hastalıklara karşı immünomodülatör aktivite gösterirler (13).

Probiyotik olarak en sık kullanılan mikroorganizmalar laktik asit bakterileri grubu (Lactobacillus, Enterococcus, vb.) ve Bifidobacterium cinsine aittir, Escherichia coli veya Saccharomyces gibi mantarlar daha az kullanılır (14). Probiyotikler ve metabolitleri, bağırsakta anti-enflamatuvar ve pro-enflamatuvar yanıtların dengelenmesine katkıda bulunur. Doğal ve özgül bağışıklık hücreleri ile bağırsak mikrobiyotası arasındaki iletişim (çapraz konuşma), bağışıkık toleransı ve enflamasyon arasındaki dengeyi kontrol eder. 


\section{1.a. Probiyotikler ve doğal bağışıklık sistemi}

Dendritik hücre $(\mathrm{DH})$ ve epitel hücreleri, doğal bağışıklıkta öne çıkan hücreler olarak genellikle bağırsak mikropları ve metabolik ürünleri ile en erken temasa geçen hücrelerdir.

1.a.1. Probiyotikler ve DH: Bağırsak DH'leri GALT'ta, bağırsak lamina propriası içine dağılmış şekilde bulunurlar (15). Antijen sensörü işlevi gören $\mathrm{DH}^{\prime} l e r$, mikroplarla temas ettiğinde, taşıdıkları Toll benzeri reseptörler ve C-tipi lektin reseptörleri ile mikrobiyal ligandları bağlar. Bu bağlanma, DH'lerin fenotiplerinde ve salgıladıkları sitokinlerinde değişikliklere yol açan farklı sinyal yolaklarını aktive eder (15). Bifidobacterium infantis 35624; lamina propriada $\mathrm{CD}_{103}{ }^{+} \mathrm{DH}^{\prime}$ lerin sayısını artırarak aktivitesini modüle edebilen probiyotiklere bir örnektir. Bu mekanizma retinoik aside bağımlıdır ve dekstran sülfat sodyum ile indüklenen kolitin şiddetinin azalmasına katkıda bulunur (16). Lactobacillus rhamnosus gibi bazı probiyotikler, DH'lerde demir-oksijenazı indükleyebilir, DH'lerin DH-SIGN ve TLR-2 reseptörlerinin bağlanma yanıtını düzenleyebilir (17). DH'lerin immünoregülasyonu ayrıca bakteri hücre duvarı bileşenleri ile de ilişkilidir. Probiyotikler bağırsaktaki bakteri popülasyonlarını organize ederek $D H^{\prime} l e r i n$ uyarılmasını düzenleyebilir. Örneğin, kapsüler polisakkarit A, plazmasitoid DH'lerin TLR-2'si ile etkileşime girerek proenflamatuvar sitokinlerin ekspresyonunu sınırlar ve fare kolit modelinde, $\mathrm{CD}^{+} \mathrm{T}$ hücreleri tarafından antienflamatuvar yanıta araclık eden IL-10 salgılanmasını uya$\operatorname{rir}(18)$.

1.a.2. Probiyotikler ve epitel hücreleri: Epitel hücreleri, bir mukozal bariyer oluşturarak konağı patojenik mikroorganizmalardan ve toksik ajanlardan korur. Bağırsak lümeni içeriği ile epitel hücreleri, lamina propria ve Peyer plaklarında bulunan bağışıklık hücreleri arasında karmaşık bir ilişki vardır (19). Probiyotikler; gerek besin maddeleri ve epitel hücresi üzerindeki bağlanma bölgeleri için patojen bakterilerle rekabet ederek gerekse diğer yollarla immünregülasyona katkıda bulunarak mukoza hasarını önlemektedir. Örneğin, Bifidobacterium infantis 35624 kökeni, Treg aktivasyonuna katkıda bulunarak ve Peyer plaklarında makrofaj enflamatuvar protein-1a (MIP-1a) ve MIP-1b salgılanmasını azaltarak Salmonella enfeksiyon hasarına karşı koruma sağlamaktadır $(20,21)$. Ek olarak, probiyotik bakteriler, insanda $\beta$-defensin-2 gibi antimikrobiyal peptitleri indükleyerek mukozal bariyer savunmalarını güçlendirmektedir. Lactobacillus casei Shirota kökeninin kolonik bağırsak hücrelerinde hBD-2 mRNA ekspresyonununu artırdığı gösterilmiştir (19). Bazı Bifidobacterium kökenleri bağırsak epitel hücrelerinde otofaji yanıtını düzenleyebilmekte, Lactobacillus rhamnosus kökenleri ise bağırsak epitel hücrelerinde Muc2 gen ekspresyonunu artırarak lokal savunmada son derece önemli olan mukusun ana bileşeni olan müsinin salgılanmasına yol açmaktadır (22). Bağırsak duvarına hasar veren enfeksiyonlarından sonra (Ör. C. difficile koliti) Lactobacillus rhamnosus L34 ve Lactobacillus casei L39 gibi probiyotikler epitelyum hücrelerinden IL-8, TNF-a gibi pro-enflamatuvar sitokinlerin salınımını azaltarak doku onarımına katkıda bulunmaktadır. Ülseratif kolitin etkilerinin azaltılmasında da probiyotiklerin rolü gösterilmiştir (23).

\section{1.b. Probiyotikler ve edinsel bağışıklık sistemi}

1.b.1. Probiyotikler ve T lenfositleri: Probiyotiklerin, alerji veya kolit gibi bazı hastalıklara karşı yararlı etkileri, Treg hücrelerin sayılarını artırma yetenekleri ile ilişkilidir (24). Bifidobacterium longum, sıçanlarda, Treg hücrelerin oranını artırarak ve Foxp3 geninde bir kaç CpG bölgesinde demetilasyona yol açmak suretiyle Treg hücrelerin uzun süreli ekspresyonunu sağlayarak kolorektal kolitin iyileşmesine katkıda bulunmaktadır $(25,26)$. Benzer şekilde, sağlıklı insanlarda B. infantis 35624 kökeni içeren probiyotik tüketiminden sonra, Foxp $3^{+}$Treg'lerin artan aktivitesi sonucu sedef hastalığı veya ülseratif kolit hastalarında proenflamatuvar sitokin düzeyleri azalmaktadır (27). Probiyotikler, kısa zincirli yağ asitleri (KZYA) gibi metabolitleriyle periferik Treg hücre miktar ve fonksiyonlarının düzenlenmesine katkıda bulunmaktadır (28). KZYA'dan bütirat, Treg hücrelerinin ekstratimik üretimini uyarmaktadır (29). KZYA; kolondaki Foxp3 ${ }^{+}$Treg hücrelerin üzerinde bulunan G-protein-bağlı 43 reseptörünü (GPR43) epigenetik modifikasyonlar ile aktive ederek kolit ve alerjik hastalıklarda iyileşmeye katkıda bulunur $(30,31)$.

Enflamatuvar bağırsak hastalıkları patogenezinde rol oynayan Th17 kaynaklı sitokinler, Bifidobacterium breve, B. longum, Lactobacillus acidophilus, B. longum subsp. infantis ve L. gasseri A5 tarafından azaltılmaktadır. Ayrıca B. breve ve L. rhamnosus GG, Th17 hücrelerin genişlemesinden, stabilizasyonundan ve şartlandırıımasından sorumlu IL-23'ü azaltmaktadır (32). Çeşitli Lactobacilli ve Bifidobacterium türlerinin Th17 üretimini aşağı yönlü regüle ettiği bilinmektedir (32).

1.b.2. Probiyotikler ve $\boldsymbol{B}$ lenfositleri: Probiyotikler, Peyer plaklarında ve lamina propriada IgA üreten hücre sayısını artırmakta ve slgA üretimini indüklemektedir (33). B lenfositler, spesifik antikorları salgılamaktan sorumlu olmaları ve humoral yanıtta ana role sahip olmalarına rağmen, otoimmün ve bulaşıcı hastalıklar sırasında IL-10 üreterek bağışıklığı negatif olarak düzenleyebilirler (34). Clostridium butyricum, spesifik immünoterapi ile kombinasyon halinde, özellikle astımlı hastalara verildiğinde antijene özgü $B$ hücrelerini, regülatör $B$ hücrelerine (Breg) dönüştürebilmektedir (35). Probiyotikler, aşıya verilen immün yanıtı da güçlendirebilmektedir. Bifidobacterium longum bv infantis CCUG 52486 kökeninin grip aşısı vd. aşılara yanıt olarak IgG üreten bellek $B$ hücrelerinin sayısını artırması buna en güzel örnektir (36).

\section{2) PREBIYOTIKLERIN IMMÜNOMODÜLATÖR ETKILERI}

Prebiyotikler "sağlığa yararlı komensal bağırsak mikrobiyotası tarafından seçici olarak kullanılan substrat" olarak tarif edilmektedir (37). Fonksiyonel gıda bileşenleri olan prebiyotikler esas olarak fruktooligosakkaritler (FOS), oligosakkarit (OSC), galaktooligosakkaritler (GOS), ksilooligosakkaritler (XOS) ve mannooligosakkaritler (MOS) gibi karbonhidratları içerirler (38). Prebiyotikler, bağırsak mikrobiyal popülasyonunun dengesini değiştirerek veya KZYA gibi anti-enflamatuvar etkili metabolitlerin üretimine katkıda bulunarak bağışıklık yanııını düzenlemektedir (39). 
Prebiyotikler, mide ve ince bağırsaktan emilmeden kolona ulaşıp kolon florasında bulunan Lactobacilli ve Bifidobacteria gibi yararlı mikrobiyal popülasyona besin kaynağı olabilen fonksiyonel gıdalardır (40). İnsan anne sütünü, GOS ve FOS ile takviye edilmiş süt tozu formülleri ile karşılaştırdığımızda prebiyotiklerin bağırsakta \%20 daha yüksek Bifidobacterium seviyeleri oluşturduğu görülmektedir (41). Bir prebiyotik olan inülin, yaşlı insanların kolon florasında Bifidobacterium düzeylerini artırmaktadır. Benzer şekilde çeşitli araştırmalar FOS ve GOS'un bifidojenik etkilerini göstermektedir (42).

Prebiyotikler ayrıca, patojen bakterilerin miktarını da azaltabilir; sığır sütü oligosakkaritleri ve süt yağı globül membranı (MFGM)-bağlantılı glikokonjugatlar, enteropatojenik bakterilerin ve enterotoksinlerin yapışmasına karşı önleyici özelliklere sahiptir (43). Ayrıca insan sütü oligosakkaritleri, kültürlenmiş epitel hücrelerine enteropatojenik Escherichia coli kökenlerinin bağlanmasını önemli ölçüde azaltır (44).

Gastrointestinal kanalda lipopolisakkaritler gibi patojenle ilişkili moleküler paternler enterositler ve bağışıklık hücreleriyle etkileşime girerek spesifik sitokin üretimini aktive ederken mikrobiyom popülasyonunda dengenin faydalı mikroplara doğru kayması, özellikle bağırsak hücrelerinin sitokin ekspresyonunu modüle etmekte, bağışıklık sistemini olumlu yönde etkilemektedir (45). B. fragilis kapsüler polisakkarit A bileşeni, Foxp $3^{+}$Treg hücrelerinin anti-enflamatuvar etkili IL-10 üretimini uyarır. Ayrıca Treg hücreleri, NOD2 reseptörlerini içeren $B$. fragilis dış zarı tarafından da uyarılır. Bu tür aktivasyonlar bağırsakta mukozal enflamasyonun baskılanmasına katkıda bulunmaktadır $(46,47)$.

\section{2.a. Prebiyotiklerin doğrudan immünomodülatör etkileri}

Prebiyotikler bağışıklık sistemi üzerinde doğrudan etki gösterebilmektedir. Sindirilemeyen oligosakkaritler (OSC) doğrudan konak mukozasındaki sinyalleri düzenleyerek bağırsak epitel hücrelerinin patojene bağlı mitojenle aktive edilen protein kinaz (MAPK) ve nükleer faktör kappa B (NF-kB)'ya karşı duyarıılığını azaltmakta, bağırsak mikrobiyotasında modifikasyona yol açmadan bağışıklık yanıtını regüle etmektedir (48). $\beta 2 \rightarrow 1$ fruktanlar da Peyer plaklarında Th1 hücrelerin yanı sıra CD11bCD103- DH'ler ile Treg hücre popülasyonunun artmasına katkıda bulunmaktadır. Ayrıca, prebiyotik karbonhidratlar; nötrofil, monosit, makrofaj ve özel bir T hücre alt grubu (timus, dalak ve ince bağırsakta bulunan) üzerinde eksprese edilen dektin-1 gibi karbonhidrat reseptörleri ile de doğrudan etkileşime girmektedir. Bu reseptörler mantar ve bitki kaynaklı çeşitli beta1,3 ve beta-1,6 bağlı glukanları polimerizasyon derecelerine göre tanıyabilme yeteneğine sahiptir. Ayrıca in vitro olarak, NK hücreleri de spesifik lektin reseptörlerine bağlanan nigero-oligosakkaritler gibi OSC'ler tarafından doğrudan aktive edilmektedir (49).

\section{2.b. Prebiyotikler ve sitokin modülasyonu}

Bir prebiyotik olan inülinin serum veya dışkıda IgG ve IgA seviyelerini modüle edebildiğini bildiren çalışmalar bulunmaktadır. FOS / inülin, oligofruktoz / inülin ve polidekstroz gibi prebiyo- tikler ise IFN-gamma, IL-1 $\beta$ ve IL-10 gibi sitokinlerin ekspresyonlarında değişikliğe yol açabilmektedir (50).

Yaşlı kişilerde galakto-oligosakkarit karışımları IL-10, IL-8, NK hücre aktivitesi ve CRP düzeyini artırırken IL-1 $\beta$ düzeyini düşürmektedir (51). İnsan periferik kan monositlerinde, FOS ve inülinin TNF-a, IL-1 $\beta$ ve IL-10 düzeylerini artırdığı ancak IL-8 düzeyini değiştirmediği gösterilmiştir (52). İnülin, keçi sütü oligosakkaritleri ve GOS, IEC18 hücrelerinde MCP1'i ve makrofaj enflamatuvar protein 2 (MIP2) salgısını artırmaktadır (48). Oligo kitosan, LPS ile uyarılmış hücrelerde NF-kB yolağının aktivasyonunu inhibe ederek NO, TNF-a ve IL-1 $\beta$ salınımını azaltmaktadır (53). Polidekstroz ile zenginleştirilmiş bebek mamalarının ise süt emen domuz yavrularında TNF-a, IL-1 $\beta$ ve IL-8 ekspresyonunu azalttığı belirlenmiş̧tir (54).

\section{2.c. Prebiyotik olarak polifenoller}

Polifenoller, bitkiler tarafından üretilen ve yine bitkilerin ultraviyole ışığa ve reaktif oksijen türlerine karşı korunmasında görev alan bileşiklerdir (55). Tanım olarak basitçe "fenolik halkalar içeren çok büyük bir bileşik grubu" olarak tarif edilse de polifenollerin yapıları, kökenleri ve işlevleri arasında büyük farklılıklar bulunmaktadır (56). Polifenollerin anti-oksidan özellikleri iyi bilinmektedir. Bununla birlikte in vitro yüksek düzeyde antioksidan etkinlik gösteren pek çok bileşik bu etkiyi in vivo koşullarda gösterememektedir (57). Bu ikilemin sebebi büyük olasılıkla, kompleks yapıdaki polifenol zincirlerinin bağırsaktan emilememesi nedeniyle biyoyararlanımlarının düşük olmasıdır (58). Bu büyük bileşikler sindirilmeden kolona ilerler ve orada bakteriler tarafından parçalanarak sindirime hazır hale gelir (59). Polifenollerin etki gösterebilmesi için emilmeleri şart değildir, zaten prebiyotikleri parçalamak için gerekli mekanizma her bakteride de bulunmamaktadır. Polifenoller, kolonda prebiyotik benzeri etki göstererek belirli bakterilerin çoğalmasına katkıda bulunmaktadır. Kırmızı şarapta bulunan polifenoller, hem sıçanlarda hem de insanlarda Bifidobacterium, Bacteroides ve Lactobacillus oranını artırmaktadır $(81,82)$. Polifenoller, faydalı bakterilerin miktarını artırmakla kalmayıp patojen bakterilerin çoğalmasına da engel olmaktadır. Çayda ve şarapta bulunan polifenoller Helicobacter pylori popülasyonunun çoğalmasını önlemekte, zeytin yağından ekstrakte edilen polifenoller ise bakterilerin verdiği zararı önlemektedir (60). Polifenoller ayrıca TLR-4 blokajı yoluyla (61) IL-1 $\beta$, IL-6 ve TNF-a gibi enflamatuvar mediyatörlerin salınımını azaltarak anti-enflamatuvar etki göstermektedir (62).

\section{2.d. Sinbiyotiklerin immünomodülatör etkileri}

Probiyotikler, bağırsaktaki etki sürelerinin artırılması amacıyla prebiyotiklerle kombine edilmiş ve böylece "sinbiyotikler" geliştirilmiştir. Sinbiyotik preparatlarda, sıklıkla Lactobacilli, Bifidobacteria spp, S. boulardii, B. coagulans gibi probiyotik kökenler ile birlikte prebiyotik olarak en çok FOS, GOS ve XOS inülin tercih edilmektedir. Örneğin, ülseratif kolitte kullanılan Bifidobacterium longum ve inülin-oligofruktoz kombinasyonu, hastalık aktivasyonu sırasında düzeyi artan insan beta defensin 2, 3 ve 4'ün mRNA seviyelerini düşürmektedir. Ayrıca bu kombinasyonun kullanımı ile TNF-a seviyesi azalmakta, IL-1a düzeyi ise sağ- 
lıklı dokulardaki konsantrasyonlara geri dönmektedir (63). Sağlıklı gönüllülere Bifidobacterium animalis ile kombine şekilde ksilo-oligosakkarit verildiğinde, NKT hücreleri üzerinde CD16 / CD56 ekspresyonu ve B hücreleri üzerinde CD19 ekspresyonu azalmaktadır (64).

Sonuç olarak, doğru seçilmiş probiyotik, prebiyotik ve sinbiyotikler ile güçlü immünomodulatör etki elde edilebilmektedir. Bir çok çalışmada, probiyotik ve prebiyotiklerin pro-enflamatuvar ve anti-enflamatuvar yanıtlar üzerindeki modülatör etkileri nedeniyle enflamasyon aracılı bir çok hastalığın (ülseratif kolit, alerjik astım, dermatit, kanser) kontrol altına alınmasında kullanılabileceği gösterilmiştir. Bununla birlikte, diyetle alınan tüm gıda bileşenleri ile fonksiyonel gıdalar (probiyotikler, prebiyotikler, mineraller, vitaminler) arasındaki dinamiğin doğru şekilde oluşturulması çok önemlidir. Epigenetik faktörler ve işlevsel mikrobiyomun katkısı ile probiyotikler ve prebiyotikler tarafından etkin bir sinyalizasyon ağı kurulabilmekte ve bu ağ, hücre-hücre iletişimi yoluyla sistemik enflamatuvar yanıtın kontrolüne katılabilmektedir.

\section{3) PROTEINLERIN IMMÜNOMODÜLATÖR ETKILERI}

İnsan vücudunda bulunan yaklaşık 100 bin farklı proteinin yaşamın devamında sayısız rolleri bulunur. Gıda proteinlerinin türevleri olan peptid fraksiyonları ise fonksiyonel gıda bileşeni olarak, antimikrobiyal, kan basıncını düzenleyici (anjiotensin dönüştürücü enzim inhibisyonu ile), kolesterol düşürücü, antitrombotik ve antioksidan etkilere sahiptir (65). Günümüzde süt proteinleri başta olmak üzere hayvansal proteinler ve bitki kaynaklı peptidlerle ilişkili çok sayıda çalışma bulunmakla birlikte bu peptidlerin potansiyel immünomodülatör etkileri görece daha az araştırılmış konular arasındadır (66).

Gıda kaynaklı peptidlerin pro- ve anti-enflamatuvar sitokinler üzerine etki ederek, immün sistemi baskılayabileceği veya harekete geçirebileceği gösterilmiştir (66). Bu etki, antikor sentezini uyarmak, T ve B lenfositler üzerine etki etmek, NK hücreleri ve makrofajların fagositoz aktivitesini düzenlemek suretiyle gerçekleşebilmektedir (67). Bu bölümde; süt ürünleri, hayvansal gıdalar, deniz ürünleri ve bitkisel proteinlerle ilgili çalışmalarda elde edilen bazı verilere yer verilecektir.

\section{3.a. Hayvansal proteinlerden elde edilen immünomodülatör peptidler}

Hayvansal gıdalar, yaşamımızda önemli yer tutar. Hayvansal proteinlerin immünite üzerindeki etkileri, dönem dönem araştırıcıların ilgisini çekmiş, özellikle süt ürünü kaynaklı proteinler daha fazla araştırılmıştır.

3.a.1.Süt proteinleri: Kazein ve peynir altı (whey) proteini gibi süt proteinleri, immünomodülatör peptidlerin öncüleri olarak tanımlanmışlardır (68). Mürin splenosit hücre kültüründe, whey proteinlerinin hidroliz sonrası kankavalin A ile muamele edildiklerinde IL-2 ve interferon gamma (IFN-gamma) düzeyinde artış görülmesi, asidik veya nötral peptid fraksiyonlarının splenosit proliferasyonunu uyarmasına bağlanmıştır (69). Ancak bir başka in vitro çalışmada, whey protein varlığında fare dalağından izole edilen lenfositlerin büyüme hızında artış gözlenmiş, fakat tripsin ve kimotripsin ile enzimatik hidroliz durumunda bu etkinin azaldığı bildirilmiştir (70). Benzer şekilde ss-laktoglobülin ile fare dalak hücreleri prolifere olurken, hidroliz ile bu etki azalmaktadır (71). Kazeinin laktobasiller tarafından proteolize uğraması, farklı immün yanıtlara yol açabilmektedir. Kazein proteinlerinin fraksiyonlarını analiz eden bir çalışmada, $a_{\mathrm{s} 1}$ fraksiyonu lenfosit proliferasyonunu baskılarken, ss ve $\mathrm{K}$ fraksiyonları proliferasyonu uyarmıştır. Sindirim enzimleri ile hidroliz öncesi Lactobacillus rhamnosus'dan elde edilen enzimler ile hidroliz uygulanması durumunda immünsüpresif etki gözlenmiş ve lenfositlerden IL-4 salınımı azalmıştır (72). Lactobacillus helveticus ile fermente olan sütü takiben oluşan immünomodülatör peptidler, bağırsak ilişkili lenfoid dokudan ve bronş ilişsili lenfoid dokudan IgA salınımını artırabilmektedir (73). Aynı çalışmada fermente sütün non-proteolitik $\mathrm{L}$. helveticus ile farelerde oral uygulaması da periton makrofajlarının aktivasyonu ve fibrosarkomda gerilemeyi beraberinde getirmiştir (73). Bu sonuç, sütün fermentasyonu ile ortaya çıkan peptidlerin de immünomodülatör etkiden sorumlu olabileceğine işaret etmektedir. Yapılan bir diğer çalışmada ise a1s-kazeinin Thr-Thr-Met-Pro-Leu-Tyr sekansının antikor yapımını, fagositik aktiviteyi, NK hücrelerin olgunlaşmasını ve lenfosit çoğalmasını artırdığı, farelerde IgA üretimini artırdığı gösterilmiştir (74). Literatürde kazeinin IgA salınımını artırıcı, makrofaj aktivasyonunu artırıcı ve lenfosit fonksiyonlarını etkileyici niteliklerini gösteren çalışmalar mevcuttur. Elde edilecek immünomodülatör etki, proteinin sindirim enzimleri ile hidrolize olup olmadığına, probiyotikler ile fermente olup olmadığına, probiyotiğin içerdiği proteolitik enzimlere ve konaktaki mevcut immün duruma göre değişkenlik göstermektedir.

3.a.2.Yumurta proteinleri: Yumurta proteinlerinden ovalbüminin ısı ile denatürasyonu neticesinde (Ör. haşlanmış yumurta) $\mathrm{CD}^{+}{ }^{+} \mathrm{T}$ hücrelerde sitokin sentezini artırabildiği, IL-12, IL-17 ve IL-10 sentezini artırıp IL-4 sentezini azalttığı gösterilmiştir (75). Ovalbümin türevi olan peptidler, makrofajlarda fagositik aktiviteyi artırmakta, aynı zamanda MAPK ve NF-kB üzerine etki etmektedir (76). Ovalbümin dışında ovotransferrin, ovomüsin, sistatin, lizozim, fosvitin, Ig Y (Yolk Immünoglobülin) gibi yumurta proteinlerinin de immünomodülatör etkileri mevcuttur. Bu proteinlerin hem pro- hem de anti-enflamatuvar sitokinleri stimüle edebildikleri gösterilmiş, ancak insanlarda fizyolojik enzimler arasındaki farklılıklar nedeniyle insan çalışmaları yapılması gerekliliği vurgulanmıştır (76).

3.a.3. Deniz ürünleri: Deniz ürünleri de önemli bir biyoaktif kaynak oluşturmaktadır ve immünomodülatör peptidler içermektedir (66). Bu konuda 2006 yılında yapılmış önemli bir çalışmada, ticari olarak piyasada olan bir balık proteini konsantresinin immün etkisi irdelenmiştir (77). Balık protein konsantresi, maya ile 24 saatlik fermantasyon ile hazırlanmıştır. Farelere bu ürünün değişik konsantrasyonları 2, 5 veya 7 gün sürelerle oral yoldan uygulanmış ve her beslenme periyodu sonunda bağırsakların histolojik incelemesi yapılarak peritoneal makrofaj aktivasyonu ve $\lg A$ salgısı konusunda sonuçlar 
bildirilmiştir. Peritoneal makrofajlarda aktivitenin arttığı, hem bağırsak hem de bronş ilişkili lenfoid dokuda IgA salgısının yanı sıra IL-4, IL-6, IL-10, IFN-gamma ve TNF-a ekpresyonunun arttığı bildirilmiştir. IFN-gamma ve TNF-a gibi pro-enflamatuvar sitokinlerde artışa karşın, normal intestinal dokuda herhangi bir enflamasyon bulgusu gözlenmezken $0.3 \mathrm{mg} / \mathrm{ml}$ dozunda 7 ardışık gün balık proteini konsantresi verildiğinde peritoneal makrofajların aktivitesinin arttığı gözlenmiştir (77). Asya'da üretilen rohu balığı yumurtasının tripsin ve alkalaz ile muamele edildiğinde bağırsak mukozal immünitesinde aktiviteyi artırdığı, tripsin hidrolizatları ile dalak $\mathrm{CD}^{+}{ }^{+}$ve $\mathrm{CD}^{+}$lenfosit sayılarını artırdığı gösterilmiştir (78). Pasifik istiridyesi ekstraktlarının, HIV ile enfekte kişilerde IL-2 indüksiyonu ile CD4+ hücre sayısında artışa katkıda bulunduğu bildirilmiş, ancak bu etki edinsel immün yetmezlik (AIDS) aşamasındaki olgularda gösterilememiştir (79).

\section{3.b. Bitkisel ürünlerden elde edilen immünomodülatör peptidler}

3.b.1. Gluten içeren baklagiller: Bitkisel proteinler ülkemiz için önemli besin kaynakları arasındadır. Ancak immünomodülatör etkileri ile ilgili araştırmalar kısıtlıdır. Buğday ve diğer baklagillerde bulunan proteinlerin yaklaşık \%80'ini gluten oluşturmaktadır (66). Buğday gluteninde amino asitlerin \%40'ını glutamil rezidüleri oluşturmaktadır. Bu özelliği ile buğday doğal bir glutamin kaynağıdır. Bağırsak ve immün sistemin hızlı bölünen hücrelerin glutamine daha fazla ihtiyacı vardır (80). Glutamin; periferik mononükleer hücrelerden TNFa salınımını azaltırken ISı şok protein (HSP) 72 salınımını artırarak, enflamatuvar süreci düzenlemektedir (81). Sağlıklı gönüllülerde yapılmış bir çalışmada günlük $3 \mathrm{gr}$ gluten hidrozilatı tüketen grupta NK hücre aktivitesinin anlamlı ölçüde arttığı gösterilmiştir (80). Enteral yolla verilen glutamin; travma hastalarında CD14+ ${ }^{+}$monositlerde HLA-DR ekspresyonunun artması ve immün fonksiyonların iyileşmesine katkıda bulunmuştur (82). Kritik hastalarla ilgili çalışmaların dahil edildiği bir metaanalizde ise, yatan hastalarda glutamin takviyesi yapıldığında nozokomiyal enfeksiyon oranlarında ve mekanik ventilasyona ihtiyaç duyulan gün sayısında düşüşs sağlandığı (orta dereceli kanıt düzeyi) sonucuna ulaşılmıştır (83).

3.b.2. Lizin içeren baklagiller: Bir başka baklagil olan nohutun ise lizin içeriği yüksektir. In vitro çalışmalarda, Caco-2 kolon tümörü hücre serisi ile THP-1 insan monositik hücre serisi kültüre edilip intestinal mekanizmanın taklit edildiği modellerde, lizin etkisi ile insan monositik hücre serisinin proliferasyonunda \%66 artış sağlamıştır (84).

3.b.3.Soya proteini: Soya, yüksek protein içeriği ile dünya genelinde yaygın tüketilen bir proteindir. Alkalaz ile muamele edilen soya proteininin, fare dalağında lenfositlerin proliferasyonuna ve periton makrofajlarının aktivasyonuna yol açtığı bildirilmiştir (85). Transplant sonrası lenfoma hastalarına ait periferik NK hücrelerinin bir soya peptidi olan lunasin ile uyarıldığı bir in vitro çalışmada ise lunasin ile uyarılan hücrelerin anti-tümör sitotoksik aktivitesinin arttığı gösterilmiştir (86).

\section{4) VITAMINLERIN IMMÜNOMODÜLATÖR ETKILERI}

4.a. A vitamini: Anti-enfektif vitamin olarak da tanınan A vitamininin hem doğal hem de edinsel bağışıklıkta rolü vardır (87). Retinol, epitelyal bütünlüğün korunmasında rol oynamaktadır. Eksikliğinde skuamöz metaplazi, epitelyal yapıda ve sekretuvar fonksiyonlarda bozulma görülebilmektedir (88). All trans retinoik asidin (atRA), T hücre stimüle edici ajanlar ile beraber uygulandığında T hücre proliferasyonunu 1.8 kat artırdığı, retinoblastoma geninin fosforilasyonunu artırarak hücre çevrimini aktive ettiği, IL-2 sekresyonunu artırdığı gösterilmiştir (89). Ayrıca timositlerin apoptoz regülasyonunda, T hücre aracılı ve antikor aracılı immün yanıtta ve kemik iliği homeostazının sağlanmasında etkili olduğu gösterilmiştir (90). A vitamini; bağırsakta bulunan $\mathrm{CD} 169^{+}$makrofajların gelişiminde rol oynar, anti-enflamatuvar etkisi bulunan M2 makrofajların çoğalmasına katkıda bulunur (91). atRA, nötrofillerin çekirdeğinde bulunan retinoik asid reseptörüne bağlanarak nötrofil diferansiyasyonunu uyarır ve mTOR sinyal yolağının aktive olması sonucunda tümör hücrelerinin etkin bir şekilde öldürülmesini sağlar (92). atRA'nın IFN-gamma düzeyini azaltarak ve IL-5 sekresyonunu artırarak NK T hücrenin erken diferansiyasyonunu uyardığını, dendritik hücreleri ve doğal lenfoid hücreleri de etkilediğini gösteren çalışmalar da mevcuttur (90). A vitamini; nötrofil diferansiyasyonunu uyarma fonksiyonu ile klinik hematolojide akut promiyelositik lösemi hastalarında remisyon indüksiyonu ve konsolidasyon tedavilerinde kullanılmaktadır (93).

4.b. B vitamini kompleksi: Metilkobalamin (B12), B vitamin kompleksi içinde en kuvvetli immünomodülatör etkiye sahip bir mikrobesindir (94). B12 vitamini eksikliğine bağlı megaloblastik anemisi bulunan hastaların kemik iliği örneklerinde yapılan incelemelerde apoptoz mekanizmasında bozulma olduğu gözlenmiştir (95). Bu biyolojik etkinin immünolojik yansımaları da mevcuttur. B12 vitamini eksikliği olan olgularda yapılmış bir çalışmada, eksiklik olan olgularda lenfositlerin, özellikle CD8 ${ }^{+}$ lenfositlerin, mutlak sayısında azalma ve CD4/CD8 oranında artış olduğu bildirilmiştir. B12 vitamini replasmanı sonrasında $\mathrm{CD}^{+}$(ve diğer) lenfosit sayılarında artışın yanı sıra NK hücre aktivitesinde de anlamlı artış olduğu gözlenmiştir (96). Ayrıca in vitro çalışmalarda B12 vitaminin anti-enflamatuvar etkileri gösterilmiş, ödem ve granülom oluşumunu azalttığı bildirilmiştir (97).

4.c. C vitamini: Nötrofillerde yüksek konsantrasyonda bulunan C vitamini, fagositik fonksiyonlarda öneme sahiptir (87). Vitamin C önemli bir antioksidandır ve hücre içinde süperoksid anyonu ile hidrojen peroksid üretimini azaltır. Vitamin $C$ uygulanması ile hücrelerin fagositik aktivitesinde düzelme olduğu, pro-enflamatuvar IL-1ss ve TNF-a salınımını in vitro azalttığı bildirilmiştir (98). Başka bir çalışmada C vitamininin doz bağımlı olarak lipopolisakkarid tarafından uyarılmış IL-6 ve TNF-a üreten monosit sayısını, aynı zamanda IL-2 üreten lenfosit sayısını azalttığı gösterilmiştir (99). Bu özellikleri ile C vitamininin doz bağımlı olarak enflamatuvar sitokinleri baskıladığı, nötrofil fonksiyonlarını ise olumlu etkilediği çıkarımı yapılabilmektedir. 
4.d. D vitamini: D vitamini, hem doğal hem özgül immünite üzerinde etkili, hem vitamin hem de hormon özelliği bulunan bir moleküldür (100). D vitamini reseptörünün makrofaj, DH, T ve B hücrelerin yüzeylerinde bulunduğu gösterilmiştir (101). Doğal immün yanıtı, hücre proliferasyonunu ve diferansiyasyonunu uyararak artırdığı bildirilmiştir (102). Doğal bağışıklığa olan etkisini Toll-like reseptorler (TLR) üzerinde göstermektedir. Zaman ve doz bağımlı olarak insan monositlerinde TLR2 ve TLR4 protein ekspresyonunu ve mRNA üretimini baskılamakta ve enflamasyonu azaltmaktadır (103). Insan hepatit C ile enfekte hepatositlerde IFN-ss'yı artırarak doğal antiviral yanıtı uyardığı gösterilmiştir (104). Edinsel immün yanıtta ise pro-enflamatuvar IL-1, TNF-a, IFN-gamma sekresyonu inhbisyonu ile Th1 hücrelerini baskılarken (105), Th2 hücrelerden IL-4 ve IL-10 gibi anti-enflamatuvar sitokin salınımını artırdığı bildirilmiş̧ir (106). D vitamini eksikliği ise enflamatuvar stres, enfeksiyon riskinde artış ve otoimmün hastalık sıklığında artış ile ilişkilendirilmiştir (100).

4.e. $\boldsymbol{E}$ vitamini: $\mathrm{E}$ vitamini, immün sistemin mikroorganizmalara karşı direncinde, kanser hücrelerine karşı reaksiyonunda ve transplante dokuya karşı yanıtta rol almaktadır (107). Yaş ile beraber T hücre fonksiyonları azalmaktayken, E vitamini özellikle naif T hücrelerdeki yaşlanma sürecini tersine çevirebilmektedir (108). Çeşitli çalışmalarda T hücre diferansiyasyonunu artırdığı ve Th hücre fonksiyonunu artırdığı, hayvan deneylerinde uzun süreli kullanımda ise T hücre fonksiyonunda iyileşme sağladığı gösterilmiştir (108). İleri evre kolorektal kanser tanılı 12 hastaya 2 hafta boyunca günlük 750 mg E vitamini verildiğinde CD4/ CD8 oranında artış, Th1 fonksiyonlarında, IL-2 ve IFN-gamma üretiminde artış gözlenmiştir. Bu sonuçlara dayanarak ve Th1 hücrelerin kansere karşı bağışıklıktaki rolü göz önüne alınarak E vitamininin, kanseri önlemede kullanılabileceği yorumu yapılmıştır (109). Aynı zamanda bu vitaminin IL-2 üretimi aracılığı ile NK aktivitesi, nötrofil kemotaksisi ve fagositozda artış sağlamak suretiyle doğal bağışık yanıtı da güçlendirdiği gösterilmiştir (108).

\section{5) MINERALLERIN IMMÜNOMODÜLATÖR ETKILERI}

5.a. Çinko: Çinko (Zn), temel hücre fonksiyonları için gerekli bir eser elementtir (100). İmmün sistemin normal fonksiyonu için çinko gerekliyken, çok miktarda alınmasının olumsuz etkisi vardır. Eksikliğinde timüs atrofisi, Th1 ve 2 miktarında dengesizlik, naif B hücrelerde azalma, Treg hücrelerde azalma ve Th17 hücrelerde artış gözlenebilmektedir (110). Doğal immünitede epitelyal membran bütünlüğü açısından gereklidir. Çinko homeostazı, Zn transport proteinleri ve metalloproteinler ile sağlanmaktadır. Çinko, hücre içinde bir sinyal molekülü olarak davranırken immün yanıtın oluşmasına da katkıda bulunur (111). Çinko eksikliğinde kompleman sistemi, NK hücre sitotoksisitesi, nötrofillerin fagositik aktivitesi, monosit ve makrofaj kemotaksisinde sorunlar ortaya çıkmaktadır (112).

5.b. Bakır: Bakır da (çinko gibi) Cu-Zn-süperoksid dismutaz enziminin kofaktörüdür (100). Nötrofil ve monositlerde hidrojen peroksid üretimini katalize eder ve makrofaj yanıtına katkıda bulunur (113). Eksikliğinde fagositik hücrelerin gelişiminde bo- zulma gözlenir. Lökositlerin mikrobisidal etkinliğinde azalma, miyeloid hücre üretiminde aksamalar gözlenmektedir (113).

5.c. Demir: Demir, T hücrelerin gelişiminde ve reaktif oksijen radikalleri oluşumunda önemli role sahiptir (100). Eksikliğinde nötrofil sayısında azalma gözlenmekle birlikte fazlalığında ise toksisiteye ve bazı patojenlerin etkisinin artmasına yol açabilir (114). Demir eksikliği olan farelerde lipopolisakkarid uyarısına karşı TNF-a, IFN-ss artışı ve TLR4 sinyal yolunda bozulma görülmektedir (115). TLR2 ve TLR4, makrofajlarda MyD88 ve TRIF sinyal yolakları aracılığı ile hepsidin ekpresyonunu düzenler (116). Makrofajlarda hepsidin birikimi, pro-enflamatuvar sitokin salınımını artırır (100). Ayrıca demir mitokondriyal reaktif oksijen radikallerini artırarak, lipopolisakkaride karşı enflamatuvar yanıtı artırır (117). Enfeksiyöz süreçlerde demir takviyesi önerilmez.

5.d. Aluminyum: Aluminyum, aşılara karşı immün yanıtın artırılması amacıyla adjuvan olarak kullanılan bir elementtir. Aluminyumun adjuvan olarak kullanıldığı aşılar, NLRP3 enflamazomunu aktive ederek IL-1ss sekresyonunu artırmak ve lokal doku hasarı oluşturmak suretiyle immün aktivasyonu sağlamaktadırlar (118). Aluminyum ayrıca kompleman kaskadında membran atak kompleksinin oluşumunda da rol almaktadır (119).

5.e. lyot: Vücutta tiroid hormon sentezinde kullanılan iyotun, normal metabolizmamızı sürdürebilmemizde hayati önemi haizdir. Hipo- ve hiper-tiroidizm durumunda NK hücre aktivitesinde bozulmalar bildirilmiştir (120). Ayrıca in vitro ortamda myeloperoksidaz aktivitesinde rol oynamaktadır ve fagositik hücrelerde fagositozun aktivasyonunda, B lenfositlerde ise lg G sentezi uyarımında rol oynar (121). Sıçanlarda yapılan çalışmalarda ise makrofajlarda artmış iyot konsatrasyonunun, antijen sunma aktivitesinde artış ile ilişkili olduğu gösterilmiştir (122).

5.f. Magnezyum: Hücresel metabolik reaksiyonlarda önemli bir rolü mevcuttur. Laboratuvar hayvanlarında kronik eksikliğinde timus atrofisi geliştiği, immün yanıtın bozulduğu ve malinitenin arttığı bildirilmiştir. Ayrıca kalsiyum ile birlikte mast hücre degranülasyonunda, dolayısıyla anafilaktik şok mekanizmasında rol oynamaktadır $(123,124)$.

5.g. Selenyum: Antioksidan etkinliği olan ve vücudun bağışıklık savunmasını destekleyen, önemli bir eser elementtir (125). Glutatyon peroksidazın önemli bir parçasıdır ve hücresel oksidasyon ürünlerinin temizlenmesinde önemlidir (126). Eksikliğinde lenfositlerin mitojenlere yanıtı bozulur, makrofajların kemotaksisinde aksamalar gözlenir ve redoks sisteminin işlememesine bağlı olarak antijen tanıma fonksiyonlarında bozukluklar gözlenir (127). Otoimmün tiroid hastalıklarına yol açtığını gösterir çalışmalar mevcuttur (122).

\section{6) FONKSIYONEL GIDALARIN IMMÜNOMODÜLA- TÖR ETKILERI}

Bağışıklık düzenleyici etkileri bulunan çok sayıda fonksiyonel gıda tanımlanmıştır. Bunlardan, günlük hayatımızda daha sık yer bulan on iki grup gıda ve gıda bileşeninin immünomodülatör etkileri Tablo 1'de özetlenmiştir. 
Tablo 1. Günlük kullanımda fonksiyonel gıdalar ve immünomodülatör etkileri

\begin{tabular}{|c|c|c|c|}
\hline Gıdalar & İmmünomodülatör Etki & Etki Mekanizması & Kaynaklar \\
\hline $\begin{array}{l}\text { 6.a. Çörek otu } \\
\text { (Nigella sativa) }\end{array}$ & $\begin{array}{l}\text { Çörek otu yağı, alerjik hastalıkların } \\
\text { semptomlarını iyileştirmede etkili. }\end{array}$ & $\begin{array}{l}\text { COX ve } 5 \text {-lipoksigenaz yolaklarını inhibe ederek } \\
\text { lökotrien ve tromboksan yapımını inhibe eder. Mast } \\
\text { hücrelerinden histamin salınımını inhibe eder. }\end{array}$ & (128) \\
\hline $\begin{array}{l}\text { 6.b. Zerdeçal } \\
\text { (Curcuma longa) }\end{array}$ & $\begin{array}{l}\text { Anjiyogenezi düzenleyerek tümör } \\
\text { büyümesini ve metastazı sınırlar, } \\
\text { diyabetik retinopati ve romatoid } \\
\text { artrite olumlu etki yapar } \\
\text { Güçlü anti-oksidan etki gösterir } \\
\text { Anti-enflamatuvar etkilidir }\end{array}$ & $\begin{array}{l}\text { PPAR- } \gamma \text { (peroxisome proliferator - activated receptor - } \gamma \text { ) } \\
\text { aktivasyonunu artırır (up-regulation) } \\
\text { Tümörleri baskılayan anti-apoptoz genlerini aşağı } \\
\text { yönde düzenler (down-regulation) } \\
\text { TNF-alfa salınımını baskılayarak sepsis gelişimine } \\
\text { karşı etki gösterir }\end{array}$ & $(129,130)$ \\
\hline $\begin{array}{l}\text { 6.c. Sarımsak } \\
\text { (Allium sativum) }\end{array}$ & $\begin{array}{l}\text { Anti-enflamatuvar } \\
\text { Anti-oksidan } \\
\text { Anti-kanser, anti-proliferatif etki } \\
\text { Anti-allerjik ve alerjen } \\
\text { Kardiyoprotektif etki } \\
\text { Obezite ve insülin direncine karşı } \\
\text { koruyucu etki }\end{array}$ & 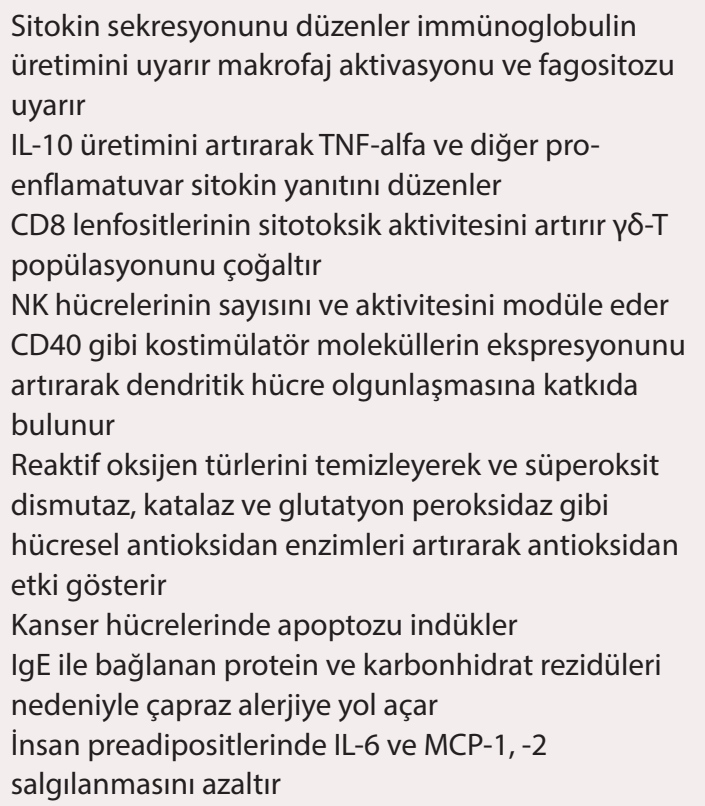 & (131) \\
\hline $\begin{array}{l}\text { 6.d. Bal, polen, arı } \\
\text { sütü, propolis }\end{array}$ & $\begin{array}{l}\text { Anti-mikrobiyal, anti-oksidan, anti- } \\
\text { enflamatuvar, anti-kanser, anti- } \\
\text { alerjen immünomodülatör }\end{array}$ & $\begin{array}{l}\text { Balın bileşiminde bulunan flavonoidler (özellikle } \\
\text { kuersetin) antiproliferatif etki gösterir } \\
\text { Tümör nekroz faktör-alfanın (TNF-a) uyarılması, } \\
\text { hücre çoğalmasının engellenmesi, apoptozun } \\
\text { uyarılması ve hücre döngüsünün engellenmesi } \\
\text { Propoliste bulunan krizin ve kampferol: anti-alerjik } \\
\text { etki gösterir }\end{array}$ & (132) \\
\hline $\begin{array}{l}\text { 6.e. Kırmızı Soğan } \\
\text { (Allium cepa Linn) }\end{array}$ & $\begin{array}{l}\text { İçeriğinde bulunan yoğun } \\
\text { flavonoidlerle; } \\
\text { Anti-oksidan, } \\
\text { İmmünomodülatör } \\
\text { Anti-kanser özelliklere sahiptir }\end{array}$ & $\begin{array}{l}\text { Kırmızı soğan, toplam aktif içeriğinin } \% 60 \text { 'ını } \\
\text { oluşturan flavonoller (kaempferol, kuersetin, } \\
\text { kuersetin dimerleri, trimerleri ve diğer kuersetin } \\
\text { glikozidleri) ile anti-oksidan, hepatoprotektif, anti- } \\
\text { kanser, anti-mikrobiyal, anti-stres etkilere sahiptir }\end{array}$ & (133) \\
\hline $\begin{array}{l}\text { 6.f. Patlıcan } \\
\text { (Solanum } \\
\text { melongena) }\end{array}$ & $\begin{array}{l}\text { Anti-oksidan ve anti-enflamatuvar } \\
\text { (siğiller, yanıklar ve stomatit, artrit } \\
\text { ve gastrit gibi birçok enflamatuvar } \\
\text { hastalıkta etkili) }\end{array}$ & $\begin{array}{l}\text { Patlıcan sapında bulunan heksan, diklorometan, etil } \\
\text { asetat, butanol; kabuğunda bulunan kafeik asit, kinik } \\
\text { asit, sinnamik asit ve klorojenik asit dahil fenoller ile } \\
\text { nasunin ve kuersetin gibi flavonoidler oksidatif stresi } \\
\text { ve anjiyogenezi önler }\end{array}$ & (134) \\
\hline
\end{tabular}




\section{6.g. Havuç (Daucus Hücresel immünitenin carota L), Kereviz düzenlenmesine katkıda bulunur: \\ (Apium graveolenz) Lenfosit aktivasyonunu ve interferon- Kişniş (Coriandrum gamma salııımını artııılar sativum), Rezene \\ (Foeniculum \\ vulgare) \\ Maydanoz \\ (Petroselinum \\ crispum) \\ Kapari (Capparis \\ Spinosa)}

6.h. Kivi Doğal bağışıklık: İçerdiği C vitamini,

(Actinidia deliciosa) karotenoidler, polifenoller ve diyet lifi ile bağırsağın mukozal savunmasını güçlendirir Adaptif bağışıklık: CD8 ${ }^{+} \mathrm{CD} 25^{+} \mathrm{T}$ hücrelerini "gençleştirir" $\gamma \delta$-T lenfositlerinin aktivasyonunu artırır

6.i. Soya fasülyesi Anti-enflamatuvar, anti-oksidan, anti(Glycine max) mutajenik, anti-karsinojen

Yapısındaki izoflavonlar, saponinler ve antosiyaninler gibi bileşenleri aracılığıyla bağışıklık modülasyonunda rol oynar

6.j. Pirinç, buğday Hububat, in vitro olarak CD141 monositlerinden IL-10 üretimini belirgin belirgin şekilde artırarak doğal bağışıklığı uyarır

6.k. Mantar

Mantar proteinleri mitojen ve immünomodülatör etki göstererek fagositleri, splenositleri, timositleri uyarır

Yeşil çay ekstresi, içerdiği

6.I. Yeşil çay
(Camellia sinensis)

flavonoidler ile anti-enflamatuvar immünomodülatör etkiye sahiptir

6.m. Aloe vera

Anti-enflamatuvar etki

Anti-astmatik etki

Anti-tümör etki

Anti-allerjik etki (özellikle lokal/ topikal)
CD8 T lenfosit proliferasyonu ve aktivasyonunu artırır (135)

Kısa zincirli yağ asitlerinin üretimini artırmak için

$(136,137)$

fermantasyon substratı olarak hareket ederek üretimini dolaylı olarak uyarır ve bu da kolon epitel hücrelerinden antimikrobiyal peptitlerin üretimini uyarır
Albatrellus confluens cinsi mantarın etken maddesi olan "Grifolin", tümör hücre hatlarında Kaspaz-8, 9, 3 aktivitesini artırarak apoptoz yolağını uyarmakta, anti-tümör etki göstermektedir

Thücrelerinin proliferasyonunu, Th1 ve Th2'ye

farklılaşmasını, IFN-gamma üretimini, makrofaj aktivasyonunu, CD4 ${ }^{+}$hücre aktivasyonunu, IL-8 ve IL-17 ve 17A üretimini artırır

Siklooksijenaz yolağını inhibe ederek araşidonik asitten prostaglandin E2 üretimini azaltır Mast hücrelerine kalsiyum girişini durdurarak antijen-antikor aracılı histamin ve lökotrien salınımını inhibe eder

Aloe veranın bir polisakkarit fraksiyonu, benzopirenin primer sıçan hepatositlerine bağlanmasını önleyerek potansiyel olarak kanseri başlatan benzopiren-DNA eklentilerinin oluşumunu önlemektedir 


\section{SONUÇ}

Gıdalar; bağırsak bağışıklık sisteminin oral tolerans, salgısal IgA, lokal lenfoid odaklar, regülatör hücresel immünite ve kommensal mikrobiyomun çeşitliliği gibi kendine özgü özellikleri ile bütünleşebildikleri ölçüde "fonksiyonel" hale gelmektedir. Doğru seçilmiş probiyotik, prebiyotik ve sinbiyotikler ile güçlü immunomodülatör etkiler elde edilebilmektedir. Probiyotik ve prebiyotikler pro-enflamatuvar ve anti-enflamatuvar yanıtlar üzerindeki modülatör etkileri nedeniyle enflamasyon aracılı bir çok hastalığın (ülseratif kolit, alerjik astım, dermatit, kanser) kontrol altına alınmasında kullanılabilmektedir. Probiyotikler, Ig G üreten bellek $B$ hücrelerini artırarak aşıya verilen immün yanıtı da güçlendirebilmektedir. Prebiyotikler, mide ve ince bağırsaktan emilmeden kolona ulaşıp kolon florasında bulunan Lactobacilli ve Bifidobacteria gibi yararlı mikrobiyal popülasyon için besin kaynağı olmakta, KZYA gibi anti-enflamatuvar etkili metabolitlerin üretimine katkıda bulunarak bağırsak bağışıklığını düzenleyen Treg hücrelerinin sayı ve aktivitesini artırmaktadır. Probiyotikler, bağırsaktaki etki sürelerinin artırılması amacıyla prebiyotiklerle kombine edilmiş ve böylece "sinbiyotikler" geliştirilmiştir.

Hayvansal proteinler ve bitki kaynaklı peptidlerin de immünomodülatör etkileri bulunmaktadır. Kazein ve whey proteini gibi süt proteinleri, immünomodülatör peptidlerin öncüleri olarak tanımlanmışlardır. Buğday ve diğer baklagillerde bulunan proteinlerin yaklaşık \%80'ini gluten, gluten yapısında ise amino asitlerin \%40'ını glutamil rezidüleri oluşturur. Yatan hastalarda glutamin takviyesi yapıldığında nozokomiyal enfeksiyon oranlarında ve mekanik ventilasyona ihtiyaç duyulan gün sayısında düşüş sağlandığı görülmüştür.

Vitaminlerden; A vitamininin mukozal epitelyal bütünlüğün korunması ve enfeksiyon etkenlerine karşı güçlü nötrofil yanıtında önemli katkıları vardır. B12 vitamini güçlü immünomodülatör etki göstermekte, özellikle CD8+ lenfosit sayılarında ve NK hücre aktivitesinde artışa katkıda bulunmaktadır. Vitamin $C$ önemli bir antioksidandır. Vitamin C uygulanması ile hücrelerin fagositik aktivitesinde düzelme olduğu, pro-enflamatuvar IL-1ss ve TNF-a salınımının azaldığı bildirilmiştir. D vitamininin, hücre proliferasyon ve diferansiyasyonunu uyararak doğal immün yanıtı güçlendirdiği bildirilmiştir. D vitamini eksikliğinde enflamatuvar stres, enfeksiyon riskinde ve otoimmün hastalık sıklığında artış görülmektedir. E vitamini özellikle naif T hücrelerdeki yaşlanma sürecini tersine çevirebilmektedir. E vitamininin, kanseri önlemede kullanılabileceği yorumu yapılmıştır. Minerallerden; çinko, hücre içinde bir sinyal molekülü olarak davranırken immün yanıtın oluşmasına da katkıda bulunur. Çinko eksikliğinde kompleman sistemi, NK hücre sitotoksisitesi, nötrofillerin fagositik aktivitesi, monosit ve makrofaj kemotaksisinde sorunlar ortaya çıkmaktadır. Bakır eksikliğinde fagositik hücrelerin gelişiminde bozulma, lökositlerin mikrobisidal etkinliğinde azalma, miyeloid hücre üretiminde aksamalar gözlenmektedir.

Sonuç olarak; beslenme ile bağışıklık arasındaki ilişkiyi inceleyen her araştırma bir kez daha Hipokrat'ı haklı çıkarmakta, gıdamız ilacımız olmaya devam etmektedir.
Ethics Committee Approval: Ethics committee approval is not required because of no material or experimental animal that would require permission.

Peer-review: Externally peer-reviewed.

Author Contributions: Concept - I.I.I.B., G.E.Y., Supervision - I.I.B., G.E.Y.; Materials - F.K.K., M.M.Ö., I.I.B., G.E.Y.; Data Collection and/or Processing - F.K.K., M.M.Ö., I.I.B., G.E.Y.; Analysis and/or Interpretation - F.K.K., M.M.Ö., I.I.B., G.E.Y.; Literature Search - F.K.K., M.M.Ö., I.I..B., G.E.Y.; Writing - F.K.K., M.M.Ö., I.I.B., G.E.Y.; Critical Reviews - F.K.K., M.M.Ö., İ.I.B., G.E.Y.

Conflict of Interest: The authors has no conflict of interest to declare.

Financial Disclosure: The authors declared that this study has received no financial support.

Etik Komite Onayı: Bu çalışmada, etik komite iznine gerek duyulacak bir materyal ya da deney hayvanı kullanılmamıştır.

Hakem Değerlendirmesi: Dış bağımsız.

Yazar Katkıları: Fkir - I.I..B., G.E.Y., Denetleme - I.I..B., G.E.Y.; Gereçler F.K.K., M.M.Ö., I.I.I.B., G.E.Y.; Veri Toplanması ve/veya Işlemesi - F.K.K., M.M.Ö., I.I.B., G.E.Y.; Analiz ve/veya Yorum - F.K.K., M.M.Ö., I.I.B., G.E.Y.; Literatür Taraması - F.K.K., M.M.Ö., I.I.I.B., G.E.Y.; Yazan - F.K.K., M.M.Ö., I.I.B., G.E.Y.; Eleştirel İnceleme - F.K.K., M.M.Ö., İ.I.B., G.E.Y.

Çıkar Çatışması: Yazarlar çıkar çatışması bildirmemiştir.

Finansal Destek: Yazarlar bu çalışmada finansal destek alınmadığını beyan etmiştir.

\section{REFERENCES}

1. Georgiou NA, Garssen J, Witkamp RF. Pharma-nutrition interface: the gap is narrowing. European Journal of Pharmacology 2011; 651(1-3): 1-8. [CrossRef]

2. TF. M. Functional Food - A Review. European Academic Research 2016(6): 5695-702.

3. Salman F, Erten G, Unal M, Kiran B, Salman S, Deniz G, et al. Effect of acute maximal exercise on lymphocyte subgroups in type $1 \mathrm{di}-$ abetes. Acta Physiol Hung 2008; 95(1): 77-86. [CrossRef]

4. Suzuki K, Kawamoto S, Maruya M, Fagarasan S. GALT: organization and dynamics leading to IgA synthesis. Advances in immunology 2010; 107: 153-85. [CrossRef]

5. Hekim N, Ş. A. Bağışıklık Bilimi. İstanbul: Nobel Tıp Kitabevleri; 2017.

6. Rezende RM, Weiner HL. History and mechanisms of oral tolerance. Seminars in Immunology 2017; 30: 3-11. [CrossRef]

7. Shiokawa A, Kotaki R, Takano T, Nakajima-Adachi H, Hachimura S. Mesenteric lymph node CD11b(-) CD103(+) PD-L1(High) dendritic cells highly induce regulatory T cells. Immunology 2017; 152(1): 52-64. [CrossRef]

8. Sato A, Hashiguchi M, Toda E, Iwasaki A, Hachimura S, Kaminogawa S. CD11 b+ Peyer's patch dendritic cells secrete IL-6 and induce IgA secretion from naive B cells. Journal of Immunology 2003; 171(7): 3684-90. [CrossRef]

9. Goodrich ME, McGee DW. Preferential enhancement of B cell IgA secretion by intestinal epithelial cell-derived cytokines and interleukin-2. Immunological Investigations 1999; 28(1): 67-75. [CrossRef] 
10. Hattori M, Taylor TD. The human intestinal microbiome: a new frontier of human biology. DNA research: An International Journal for Rapid Publication of Reports on Genes and Genomes 2009; 16(1): 1-12. [CrossRef]

11. Yanagibashi T, Hosono A, Oyama A, Tsuda M, Suzuki A, Hachimura $\mathrm{S}$, et al. IgA production in the large intestine is modulated by a different mechanism than in the small intestine: Bacteroides acidifaciens promotes IgA production in the large intestine by inducing germinal center formation and increasing the number of $\lg A+B$ cells. Immunobiology 2013; 218(4): 645-51. [CrossRef]

12. Sudo N, Sawamura S, Tanaka K, Aiba Y, Kubo C, Koga Y. The requirement of intestinal bacterial flora for the development of an $\lg \mathrm{E}$ production system fully susceptible to oral tolerance induction. Journal of Immunology 1997; 159(4): 1739-45.

13. Kang HJ, Im SH. Probiotics as an Immune Modulator. Journal of Nutritional Science and Vitaminology 2015; 61(Suppl): S103-5. [CrossRef]

14. Saad N, Delattre C, Urdaci M, Schmitter JM, P.Bressollier. An overview of the last advances in probiotic and prebiotic field. LWT Food Science and Technology 2013; 50(1): 1-16. [CrossRef]

15. Schiavi E, Smolinska S, O'Mahony L. Intestinal dendritic cells. Current Opinion in Gastroenterology 2015; 31(2): 98-103. [CrossRef]

16. Konieczna P, Ferstl R, Ziegler M, Frei R, Nehrbass D, Lauener RP, et al. Immunomodulation by Bifidobacterium infantis 35624 in the murine lamina propria requires retinoic acid-dependent and independent mechanisms. PloS One 2013; 8(5): e62617. [CrossRef]

17. Wong TH, Chen HA, Gau RJ, Yen JH, Suen JL. Heme Oxygenase-1-Expressing Dendritic Cells Promote Foxp3+ Regulatory $\mathrm{T}$ Cell Differentiation and Induce Less Severe Airway Inflammation in Murine Models. PloS One 2016; 11(12): e0168919. [CrossRef]

18. Dasgupta S, Erturk-Hasdemir D, Ochoa-Reparaz J, Reinecker HC, Kasper DL. Plasmacytoid dendritic cells mediate anti-inflammatory responses to a gut commensal molecule via both innate and adaptive mechanisms. Cell Host \& Microbe 2014; 15(4): 413-23. [CrossRef]

19. Habil N, Abate W, Beal J, Foey AD. Heat-killed probiotic bacteria differentially regulate colonic epithelial cell production of human beta-defensin-2: dependence on inflammatory cytokines. Beneficial Microbes 2014; 5(4): 483-95. [CrossRef]

20. Hemaiswarya S, Raja R, Ravikumar R, IS C. Mechanism of action of probiotics. Braz Arch Biol Technol 2013; 56: 113-9. [CrossRef]

21. Scully P, Macsharry J, O'Mahony D, Lyons A, O'Brien F, Murphy S, et al. Bifidobacterium infantis suppression of Peyer's patch MIP-1alpha and MIP-1beta secretion during Salmonella infection correlates with increased local CD4+CD25+ T cell numbers. Cellular Immunology 2013; 281(2): 134-40. [CrossRef]

22. Lin R, Jiang Y, Zhao XY, Guan Y, Qian W, Fu XC, et al. Four types of Bifidobacteria trigger autophagy response in intestinal epithelial cells. Journal of Digestive Diseases 2014; 15(11): 597-605. [CrossRef]

23. Elian SD, Souza EL, Vieira AT, Teixeira MM, Arantes RM, Nicoli JR, et al. Bifidobacterium longum subsp. infantis BB-02 attenuates acute murine experimental model of inflammatory bowel disease. Beneficial Microbes 2015; 6(3): 277-86. [CrossRef]

24. Kim HJ, Kim YJ, Lee SH, Yu J, Jeong SK, Hong SJ. Effects of Lactobacillus rhamnosus on allergic march model by suppressing Th2, Th17, and TSLP responses via CD4(+)CD25(+)Foxp3(+) Tregs. Clinical Immunology 2014; 153(1): 178-86. [CrossRef]

25. Zhang M, Zhang S, Hua Z, X Z. Long-term use of Bifidobacterium longum alleviates colorectal colitis in rats by regulating inflammatory cytokines and Treg cells. Erciyes Üniversitesi Veterinerlik Fakültesi Dergisi 2017(10): 7543-52.
26. Zhang $M$, Zhou L, Zhang S, Yang Y, Xu L, Hua Z, et al. Bifidobacterium longum affects the methylation level of forkhead box $\mathrm{P} 3$ promoter in 2, 4, 6-trinitrobenzenesulphonic acid induced colitis in rats. Microbial Pathogenesis 2017; 110: 426-30. [CrossRef]

27. Konieczna P, Schiavi E, Ziegler M, Groeger D, Healy S, Grant R, et al. Human dendritic cell DC-SIGN and TLR-2 mediate complementary immune regulatory activities in response to Lactobacillus rhamnosus JB-1. PloS One 2015; 10(3): e0120261. [CrossRef]

28. Atarashi K, Tanoue T, Oshima K, Suda W, Nagano Y, Nishikawa H, et al. Treg induction by a rationally selected mixture of Clostridia strains from the human microbiota. Nature 2013; 500(7461): 2326. [CrossRef]

29. Furusawa Y, Obata Y, Fukuda S, Endo TA, Nakato G, Takahashi D, et al. Commensal microbe-derived butyrate induces the differentiation of colonic regulatory T cells. Nature 2013; 504(7480): 446-50. [CrossRef]

30. Arpaia N, Campbell C, Fan X, Dikiy S, van der Veeken J, deRoos $P$, et al. Metabolites produced by commensal bacteria promote peripheral regulatory T-cell generation. Nature 2013; 504(7480): 451-5. [CrossRef]

31. Milligan G, Ulven T, Murdoch H, Hudson BD. G-protein-coupled receptors for free fatty acids: nutritional and therapeutic targets. The British Journal of Nutrition 2014; 111 (Suppl 1): S3-7. [CrossRef]

32. Owaga E, Hsieh RH, Mugendi B, Masuku S, Shih CK, Chang JS. Th17 Cells as Potential Probiotic Therapeutic Targets in Inflammatory Bowel Diseases. International Journal of Molecular Sciences 2015; 16(9): 20841-58. [CrossRef]

33. Sakai F, Hosoya T, Ono-Ohmachi A, Ukibe K, Ogawa A, Moriya T, et al. Lactobacillus gasseri SBT2055 induces TGF-beta expression in dendritic cells and activates TLR2 signal to produce IgA in the small intestine. PloS One 2014; 9(8): e105370. [CrossRef]

34. Rosser EC, Oleinika K, Tonon S, Doyle R, Bosma A, Carter NA, et al. Regulatory $B$ cells are induced by gut microbiota-driven interleukin-1beta and interleukin-6 production. Nature Medicine 2014; 20(11): 1334-9. [CrossRef]

35. Liao HY, Tao L, Zhao J, Qin J, Zeng GC, Cai SW, et al. Clostridium butyricum in combination with specific immunotherapy converts antigen-specific B cells to regulatory B cells in asthmatic patients. Scientific Reports 2016; 6: 20481. [CrossRef]

36. Enani SM, Childs CE, Przemska A, Maidens C, Dong H, Rowland I, et al. Effects of a novel probiotic, Bifidobacterium longum bv. infantis CCUG 52486 with prebiotic on the B-cell response to influenza vaccination. Proceedings of the Nutrition Society 2014(73): E9. [CrossRef]

37. Gibson GR, Hutkins R, Sanders ME, Prescott SL, Reimer RA, Salminen SJ, et al. Expert consensus document: The International Scientific Association for Probiotics and Prebiotics (ISAPP) consensus statement on the definition and scope of prebiotics. Nature reviews Gastroenterology \& Hepatology 2017; 14(8): 491-502. [CrossRef]

38. Shokryazdan P, Faseleh Jahromi M, Navidshad B, Liang JB. Effects of prebiotics on immune system and cytokine expression. Medical Microbiology and Immunology 2017; 206(1): 1-9. [CrossRef]

39. Dwivedi M, Kumar P, Laddha NC, Kemp EH. Induction of regulatory T cells: A role for probiotics and prebiotics to suppress autoimmunity. Autoimmunity Reviews 2016; 15(4): 379-92. [CrossRef]

40. Bindels LB, Delzenne NM, Cani PD, Walter J. Towards a more comprehensive concept for prebiotics. Nature reviews Gastroenterology \& Hepatology 2015; 12(5): 303-10. [CrossRef]

41. Oozeer R, van Limpt K, Ludwig T, Ben Amor K, Martin R, Wind $R D$, et al. Intestinal microbiology in early life: specific prebiotics can have similar functionalities as human-milk oligosaccharides. The American Journal of Clinical Nutrition 2013; 98(2): 561S-71S. [CrossRef] 
42. Voreades N, Kozil A, Weir TL. Diet and the development of the human intestinal microbiome. Frontiers in Microbiology 2014; 5: 494. [CrossRef]

43. Douellou T, Montel MC, Thevenot Sergentet D. Invited review: Anti-adhesive properties of bovine oligosaccharides and bovine milk fat globule membrane-associated glycoconjugates against bacterial food enteropathogens. Journal of Dairy Science 2017; 100(5): 3348-59. [CrossRef]

44. Manthey CF, Autran CA, Eckmann L, Bode L. Human milk oligosaccharides protect against enteropathogenic Escherichia coli attachment in vitro and EPEC colonization in suckling mice. Journal of Pediatric Gastroenterology and Nutrition 2014; 58(2): 165-8. [CrossRef]

45. Honda K, Littman DR. The microbiota in adaptive immune homeostasis and disease. Nature 2016; 535(7610): 75-84. [CrossRef]

46. Chu H, Khosravi A, Kusumawardhani IP, Kwon AH, Vasconcelos $A C$, Cunha LD, et al. Gene-microbiota interactions contribute to the pathogenesis of inflammatory bowel disease. Science 2016; 352(6289): 1116-20. [CrossRef]

47. Donaldson GP, Lee SM, Mazmanian SK. Gut biogeography of the bacterial microbiota. Nature Reviews Microbiology 2016; 14(1): 20-32. [CrossRef]

48. Wu RY, Maattanen P, Napper S, Scruten E, Li B, Koike Y, et al. Non-digestible oligosaccharides directly regulate host kinome to modulate host inflammatory responses without alterations in the gut microbiota. Microbiome 2017; 5(1): 135. [CrossRef]

49. Seifert S, Watzl B. Inulin and oligofructose: review of experimental data on immune modulation. The Journal of Nutrition 2007; 137(11 Suppl): 2563S-7S. [CrossRef]

50. Vogt L, Meyer D, Pullens G, Faas M, Smelt M, Venema K, et al. Immunological properties of inulin-type fructans. Critical Reviews in Food Science and Nutrition 2015; 55(3): 414-36. [CrossRef]

51. Vulevic J, Drakoularakou A, Yaqoob P, Tzortzis G, Gibson GR. Modulation of the fecal microflora profile and immune function by a novel trans-galactooligosaccharide mixture (B-GOS) in healthy elderly volunteers. The American Journal of Clinical Nutrition 2008; 88(5): 1438-46.

52. Capitan-Canadas F, Ortega-Gonzalez M, Guadix E, Zarzuelo A, Suarez MD, de Medina FS, et al. Prebiotic oligosaccharides directly modulate proinflammatory cytokine production in monocytes via activation of TLR4. Molecular Nutrition \& Food Research 2014; 58(5): 1098-110. [CrossRef]

53. Zhu J, Zhang Y, Wu G, Xiao Z, Zhou H, Yu X. Inhibitory effects of oligochitosan on TNF-alpha, IL-1 beta and nitric oxide production in lipopolysaccharide-induced RAW264.7 cells. Molecular Medicine Reports 2015; 11(1): 729-33. [CrossRef]

54. Herfel TM, Jacobi SK, Lin X, Fellner V, Walker DC, Jouni ZE, et al. Polydextrose enrichment of infant formula demonstrates prebiotic characteristics by altering intestinal microbiota, organic acid concentrations, and cytokine expression in suckling piglets. The Journal Of Nutrition 2011; 141(12): 2139-45. [CrossRef]

55. Agati G, Brunetti C, Di Ferdinando M, Ferrini F, Pollastri S, Tattini M. Functional roles of flavonoids in photoprotection: new evidence, lessons from the past. Plant Physiology and Biochemistry : PPB 2013; 72: 35-45. [CrossRef]

56. Tsao R. Chemistry and biochemistry of dietary polyphenols. Nutrients 2010; 2(12): 1231-46. [CrossRef]

57. Mao X, Gu C, Chen D, Yu B, He J. Oxidative stress-induced diseases and tea polyphenols. Oncotarget 2017; 8(46): 81649-61. [CrossRef]
58. Scholz S, Williamson G. Interactions affecting the bioavailability of dietary polyphenols in vivo. International journal for vitamin and nutrition research Internationale Zeitschrift fur Vitamin- und Ernahrungsforschung Journal International de Vitaminologie et de Nutrition 2007; 77(3): 224-35. [CrossRef]

59. de Ferrars RM, Czank C, Zhang Q, Botting NP, Kroon PA, Cassidy A, et al. The pharmacokinetics of anthocyanins and their metabolites in humans. British Journal of Pharmacology 2014; 171(13): 326882. [CrossRef]

60. Ruggiero P, Tombola F, Rossi G, Pancotto L, Lauretti L, Del Giudice $\mathrm{G}$, et al. Polyphenols reduce gastritis induced by Helicobacter pylori infection or VacA toxin administration in mice. Antimicrobial Agents and Chemotherapy 2006; 50(7): 2550-2. [CrossRef]

61. Huang S, Zhao L, Kim K, Lee DS, Hwang DH. Inhibition of Nod2 signaling and target gene expression by curcumin. Molecular Pharmacology 2008; 74(1): 274-81. [CrossRef]

62. Olivera A, Moore TW, Hu F, Brown AP, Sun A, Liotta DC, et al. Inhibition of the NF-kappaB signaling pathway by the curcumin analog, 3,5-Bis(2-pyridinylmethylidene)-4-piperidone (EF31): anti-inflammatory and anti-cancer properties. International Immunopharmacology 2012; 12(2): 368-77. [CrossRef]

63. Derikx LA, Dieleman LA, Hoentjen F. Probiotics and prebiotics in ulcerative colitis. Best Practice \& Research Clinical Gastroenterology 2016; 30(1): 55-71. [CrossRef]

64. Childs CE, Roytio H, Alhoniemi E, Fekete AA, Forssten SD, Hudjec $\mathrm{N}$, et al. Xylo-oligosaccharides alone or in synbiotic combination with Bifidobacterium animalis subsp. lactis induce bifidogenesis and modulate markers of immune function in healthy adults: a double-blind, placebo-controlled, randomised, factorial crossover study. The British Journal of Nutrition 2014; 111(11): 1945-56. [CrossRef]

65. Hartmann R, Meisel H. Food-derived peptides with biological activity: from research to food applications. Current Opinion in Biotechnology 2007; 18(2): 163-9. [CrossRef]

66. Santiago-Lopez L, Hernandez-Mendoza A, Vallejo-Cordoba B, Mata-Haro V, Gonzalez-Cordova AF. Food-derived immunomodulatory peptides. Journal of the Science of Food and Agriculture 2016; 96(11): 3631-41. [CrossRef]

67. Wagar LE, Champagne CP, Buckley ND, Raymond Y, Green-Johnson JM. Immunomodulatory properties of fermented soy and dairy milks prepared with lactic acid bacteria. Journal of Food Science 2009(74): M423-M30. [CrossRef]

68. Meisel $\mathrm{H}$. Biochemical properties of peptides encrypted in bovine milk proteins. Current Medicinal Chemistry 2005; 12(16): 1905-19. [CrossRef]

69. Saint-Sauveur D, Gauthier SF, Boutin Y, A M. Immunomodulating properties of a whey protein isolate, its enzymatic digest and peptide fractions. International Dairy Journal 2008(18): 260-70. [CrossRef]

70. Jang A, Jo C, Kang K-S, ML. Antimicrobial and human cancer cell cytotoxic effect of synthetic angiotensin converting enzyme (ACE) inhibitory peptides. Food Chemistry 2008(107): 327-36. [CrossRef]

71. Jacquot A, Gauthier SF, Drouin R, YB. Proliferative effects of synthetic peptides from beta-lactoglobulin and alpha-lactalbumin on murine splenocytes. International Dairy Journal 2010(20): 51421. [CrossRef]

72. Sutas Y, Soppi E, Korhonen H, Syvaoja EL, Saxelin M, Rokka T, et al. Suppression of lymphocyte proliferation in vitro by bovine caseins hydrolyzed with Lactobacillus casei GG-derived enzymes. The Journal of Allergy and Clinical Immunology 1996; 98(1): 216-24. [CrossRef] 
73. Matar C, Valdez JC, Medina M, Rachid M, Perdigon G. Immunomodulating effects of milks fermented by Lactobacillus helveticus and its non-proteolytic variant. The Journal of Dairy Research 2001; 68(4): 601-9. [CrossRef]

74. Jolles P, Fiat A-M, Migliore-Samour D, Douet $L, J$ C. Peptides from milk proteins implicated in antithrombosis and immunomodulation. New Perspectives in Infant Nutrition: Symposium Antwerp. New York, NY: Thieme Medical Publishers; 1992. p. 160-72.

75. Rupa P, L. Schnarr, Mine Y. Effect of heat denaturation of egg white proteins ovalbumin and ovomucoid on CD4+ T cell cytokine production and human mast cell histamine production. Journal of Functional Foods 2015(18): 28-34. [CrossRef]

76. Lee $\mathrm{JH}$, Paik HD. Anticancer and immunomodulatory activity of egg proteins and peptides: a review. Poultry Science 2019; 98(12): 6505-16. [CrossRef]

77. Duarte J, Vinderola G, Ritz B, Perdigon G, Matar C. Immunomodulating capacity of commercial fish protein hydrolysate for diet supplementation. Immunobiology 2006; 211(5): 341-50. [CrossRef]

78. Chalamaiah M, Jyothirmayi T, Diwan PV, Dinesh Kumar B. Antiproliferative, ACE-inhibitory and functional properties of protein hydrolysates from rohu (Labeo rohita) roe (egg) prepared by gastrointestinal proteases. Journal of Food Science and Technology 2015; 52(12): 8300-7. [CrossRef]

79. Achour A, Lachgar A, Astgen A, Chams V, Bizzini B, Tapiero H, et al. Potentialization of IL-2 effects on immune cells by oyster extract (JCOE) in normal and HIV-infected individuals. Biomedicine \& pharmacotherapy = Biomedecine \& Pharmacotherapie 1997; 51(10): 427-9. [CrossRef]

80. Horiguchi N, Horiguchi H, Suzuki Y. Effect of wheat gluten hydrolysate on the immune system in healthy human subjects. Bioscience, Biotechnology, and Biochemistry 2005; 69(12): 2445-9. [CrossRef]

81. Wischmeyer PE, Riehm J, Singleton KD, Ren H, Musch MW, Kahana $M$, et al. Glutamine attenuates tumor necrosis factor-alpha release and enhances heat shock protein 72 in human peripheral blood mononuclear cells. Nutrition 2003; 19(1): 1-6. [CrossRef]

82. Boelens PG, Houdijk AP, Fonk JC, Nijveldt RJ, Ferwerda CC, Von Blomberg-Van Der Flier BM, et al. Glutamine-enriched enteral nutrition increases HLA-DR expression on monocytes of trauma patients. The Journal of Nutrition 2002; 132(9): 2580-6. [CrossRef]

83. Tao KM, Li XQ, Yang LQ, Yu WF, Lu ZJ, Sun YM, et al. Glutamine supplementation for critically ill adults. The Cochrane Database of Systematic Reviews 2014(9): CD010050. [CrossRef]

84. Girón-Calle J, Alaiz M, J V. Effect of chickpea protein hydrolysates on cell proliferation and in vitro bioavailability. Food Research International 2010; 43(5). [CrossRef]

85. Kong X, Guo M, Hua Y, Cao D, Zhang C. Enzymatic preparation of immunomodulating hydrolysates from soy proteins. Bioresource Technology 2008; 99(18): 8873-9. [CrossRef]

86. Chang HC, Lewis D, Tung CY, Han L, Henriquez SM, Voiles L, et al. Soypeptide lunasin in cytokine immunotherapy for lymphoma. Cancer Immunology, Immunotherapy : CII 2014; 63(3): 283-95. [CrossRef]

87. Mahima, Ingle AM, Verma AK, Tiwari R, Karthik K, Chakraborty S, et al. Immunomodulators in day to day life: a review. Pakistan Journal of Biological Sciences : PJBS 2013; 16(17): 826-43. [CrossRef]

88. Quadro L, Gamble MV, Vogel S, Lima AA, Piantedosi R, Moore SR, et al. Retinol and retinol-binding protein: gut integrity and circulating immunoglobulins. The Journal of Infectious Diseases 2000; 182(Suppl 1): S97-S102. [CrossRef]
89. Ertesvag A, Engedal N, Naderi S, Blomhoff HK. Retinoic acid stimulates the cell cycle machinery in normal T cells: involvement of retinoic acid receptor-mediated IL-2 secretion. Journal of Immunology 2002; 169(10): 5555-63. [CrossRef]

90. Huang Z, Liu Y, Qi G, Brand D, Zheng SG. Role of Vitamin A in the Immune System. Journal of Clinical Medicine 2018; 7(9). [CrossRef]

91. Pereira WF, Ribeiro-Gomes FL, Guillermo LV, Vellozo NS, Montalvao F, Dosreis GA, et al. Myeloid-derived suppressor cells help protective immunity to Leishmania major infection despite suppressed T cell responses. Journal of Leukocyte Biology 2011; 90(6): 1191-7. [CrossRef]

92. Shrestha S, Kim SY, Yun YJ, Kim JK, Lee JM, Shin M, et al. Retinoic acid induces hypersegmentation and enhances cytotoxicity of neutrophils against cancer cells. Immunology Letters 2017; 182: 24-9. [CrossRef]

93. Fenaux $\mathrm{P}$, Chastang $\mathrm{C}$, Chevret $\mathrm{S}$, Sanz M, Dombret $\mathrm{H}$, Archimbaud $E$, et al. A randomized comparison of all transretinoic acid (ATRA) followed by chemotherapy and ATRA plus chemotherapy and the role of maintenance therapy in newly diagnosed acute promyelocytic leukemia. The European APL Group. Blood 1999; 94(4): 1192200. [CrossRef]

94. Sakane T, Takada S, Kotani H, Tsunematsu T. Effects of methyl-B12 on the in vitro immune functions of human T lymphocytes. Journal of Clinical Immunology 1982; 2(2): 101-9. [CrossRef]

95. Ingram CF, Davidoff AN, Marais E, Sherman GG, Mendelow BV. Evaluation of DNA analysis for evidence of apoptosis in megaloblastic anaemia. British Journal of Haematology 1997; 96(3): 576-83. [CrossRef]

96. Tamura J, Kubota K, Murakami H, Sawamura M, Matsushima T, Tamura $\mathrm{T}$, et al. Immunomodulation by vitamin B12: augmentation of CD8+ T lymphocytes and natural killer (NK) cell activity in vitamin B12-deficient patients by methyl-B12 treatment. Clinical and Experimental Immunology 1999; 116(1): 28-32. [CrossRef]

97. Hosseinzadeh H, Moallem SA, Moshiri M, Sarnavazi MS, Etemad L. Anti-nociceptive and anti-inflammatory effects of cyanocobalamin (vitamin B12) against acute and chronic pain and inflammation in mice. Arzneimittel-Forschung 2012; 62(7): 324-9. [CrossRef]

98. Guerra BA, Bolin AP, Otton R. Carbonyl stress and a combination of astaxanthin/vitamin $C$ induce biochemical changes in human neutrophils. Toxicology in vitro : an international journal published in association with BIBRA 2012; 26(7): 1181-90. [CrossRef]

99. Hartel C, Strunk T, Bucsky P, Schultz C. Effects of vitamin C on intracytoplasmic cytokine production in human whole blood monocytes and lymphocytes. Cytokine 2004; 27(4-5): 101-6. [CrossRef]

100. El-Zayat SR, Sibaii H, FA. M. Micronutrients and many important factors that affect the physiological functions of toll-like receptors. Bulletin of the National Research Centre 2019; 43: 123. [CrossRef]

101. Korf H, Decallonne B, Mathieu C. Vitamin D for infections. Current opinion in Endocrinology, Diabetes, and Obesity 2014; 21 (6): 4316. [CrossRef]

102. Myszka M, Klinger M. [The immunomodulatory role of Vitamin D]. Postepy Higieny i Medycyny Doswiadczalnej 2014; 68: 865-78. [CrossRef]

103. Sadeghi K, Wessner B, Laggner U, Ploder M, Tamandl D, Friedl J, et al. Vitamin D3 down-regulates monocyte TLR expression and triggers hyporesponsiveness to pathogen-associated molecular patterns. European Journal of Immunology 2006; 36(2): 361-70. [CrossRef]

104. Gal-Tanamy M, Bachmetov L, Ravid A, Koren R, Erman A, Tur-Kaspa $\mathrm{R}$, et al. Vitamin D: an innate antiviral agent suppressing hepatitis $C$ virus in human hepatocytes. Hepatology 2011; 54(5): 1570-9. [CrossRef] 
105. Battault S, Whiting SJ, Peltier SL, Sadrin S, Gerber G, Maixent JM. Vitamin D metabolism, functions and needs: from science to health claims. European Journal of Nutrition 2013; 52(2): 429-41. [CrossRef]

106. Pettengill MA, van Haren SD, Levy O. Soluble mediators regulating immunity in early life. Frontiers in Immunology 2014; 5: 457. [CrossRef]

107. Pekmezci D. Vitamin E and immunity. Vitamins and Hormones 2011; 86: 179-215. [CrossRef]

108. Wu D, Meydani SN. Age-associated changes in immune and inflammatory responses: impact of vitamin $\mathrm{E}$ intervention. Journal of Leukocyte Biology 2008; 84(4): 900-14. [CrossRef]

109. Malmberg KJ, Lenkei R, Petersson M, Ohlum T, Ichihara F, Glimelius $B$, et al. A short-term dietary supplementation of high doses of vitamin $\mathrm{E}$ increases $\mathrm{T}$ helper 1 cytokine production in patients with advanced colorectal cancer. Clinical cancer research : an official journal of the American Association for Cancer Research 2002; 8(6): 1772-8.

110. Wessels I, Maywald M, Rink L. Zinc as a Gatekeeper of Immune Function. Nutrients 2017; 9(12). [CrossRef]

111. Hojyo S, Fukada T. Roles of Zinc Signaling in the Immune System. Journal of Immunology Research 2016; 2016: 6762343. [CrossRef]

112. Gammoh NZ, Rink L. Zinc in Infection and Inflammation. Nutrients 2017; 9(6). [CrossRef]

113. Veldhuis NA, Valova VA, Gaeth AP, Palstra N, Hannan KM, Michell $B J$, et al. Phosphorylation regulates copper-responsive trafficking of the Menkes copper transporting P-type ATPase. The International Journal of Biochemistry \& Cell Biology 2009; 41(12): 240312. [CrossRef]

114. Katona $\mathrm{P}$, Katona-Apte J. The interaction between nutrition and infection. Clinical infectious diseases : an official publication of the Infectious Diseases Society of America 2008; 46(10): 1582-8. [CrossRef]

115. Albiger B, Sandgren A, Katsuragi H, Meyer-Hoffert U, Beiter K, Wartha $F$, et al. Myeloid differentiation factor 88-dependent signalling controls bacterial growth during colonization and systemic pneumococcal disease in mice. Cellular Microbiology 2005; 7(11): 160315. [CrossRef]

116. Balounova J, Vavrochova T, Benesova M, Ballek O, Kolar M, Filipp D. Toll-like receptors expressed on embryonic macrophages couple inflammatory signals to iron metabolism during early ontogenesis. European Journal of Immunology 2014; 44(5): 1491-502. [CrossRef]

117. Hoeft K, Bloch DB, Graw JA, Malhotra R, Ichinose F, Bagchi A. Iron Loading Exaggerates the Inflammatory Response to the Toll-like Receptor 4 Ligand Lipopolysaccharide by Altering Mitochondrial Homeostasis. Anesthesiology 2017; 127(1): 121-35. [CrossRef]

118. Wang C, Zhang R, Wei X, Lv M, Jiang Z. Metalloimmunology: The metal ion-controlled immunity. Advances in Immunology 2020; 145: 187-241. [CrossRef]

119. Guven E, Duus K, Laursen I, Hojrup P, Houen G. Aluminum hydroxide adjuvant differentially activates the three complement pathways with major involvement of the alternative pathway. PloS One 2013; 8(9): e74445. [CrossRef]

120. Wenzel BE, Chow A, Baur R, Schleusener H, Wall JR. Natural killer cell activity in patients with Graves' disease and Hashimoto's thyroiditis. Thyroid 1998; 8(11): 1019-22. [CrossRef]

121. Venturi S, Donati FM, Venturi A, Venturi M, Grossi L, Guidi A. Role of iodine in evolution and carcinogenesis of thyroid, breast and stomach. Adv Clin Path 2000; 4(1): 11-7.

122. Zhao SJ, Sun FJ, Tian EJ, Chen ZP. [The effects of iodine/selenium on the function of antigen presentation of peritoneal macrophages in rats]. Zhonghua Yu Fang Yi Xue Za Zhi 2008; 42(7): 485-8.
123. Sampson HA. Food allergy. Part 1: immunopathogenesis and clinical disorders. The Journal of Allergy and Clinical Immunology 1999; 103(5 Pt 1): 717-28. [CrossRef]

124. Ashkenazy Y, Moshonov S, Fischer G, Feigel D, Caspi A, Kusniec F, et al. Magnesium-deficient diet aggravates anaphylactic shock and promotes cardiac myolysis in guinea pigs. Magnes Trace El 1990; 9(5): 283-8.

125. Puertollano MA, Puertollano E, de Cienfuegos GA, de Pablo MA. Dietary antioxidants: immunity and host defense. Curr Top Med Chem 2011; 11(14): 1752-66. [CrossRef]

126. Huang Z, Rose AH, Hoffmann PR. The role of selenium in inflammation and immunity: from molecular mechanisms to therapeutic opportunities. Antioxid Redox Signal 2012; 16(7): 705-43. [CrossRef]

127. Ren F, Chen X, Hesketh J, Gan F, Huang K. Selenium promotes T-cell response to TCR-stimulation and ConA, but not PHA in primary porcine splenocytes. PloS One 2012; 7(4): e35375. [CrossRef]

128. Buyukozturk S, Gelincik A, Ozseker F, Genc S, Savran FO, Kiran B, et al. Nigella sativa (black seed) oil does not affect the T-helper 1 and T-helper 2 type cytokine production from splenic mononuclear cells in allergen sensitized mice. J Ethnopharmacol 2005; 100(3): 295-8. [CrossRef]

129. Jacob A, Wu R, Zhou M, Wang P. Mechanism of the Anti-inflammatory Effect of Curcumin: PPAR-gamma Activation. PPAR Research 2007; 2007: 89369. [CrossRef]

130. Al-Suhaimi EA, Al-Riziza NA, Al-Essa RA. Physiological and therapeutical roles of ginger and turmeric on endocrine functions. The American journal of Chinese Medicine 2011; 39(2): 215-31. [CrossRef]

131. Arreola R, Quintero-Fabian S, Lopez-Roa RI, Flores-Gutierrez EO, Reyes-Grajeda JP, Carrera-Quintanar L, et al. Immunomodulation and anti-inflammatory effects of garlic compounds. Journal of Immunology Research 2015; 2015: 401630. [CrossRef]

132. Onbaşlı D, Çelik GY, Kahraman S, MK. Apiterapi ve İnsan Sağlığı Üzerine Etkileri Erciyes Üniversitesi Veterinerlik Fakültesi Dergisi 2019; 16(1): 49-56. [CrossRef]

133. Elberry AA, Mufti S, Al-Maghrabi J, Abdel Sattar E, Ghareib SA, Mosli HA, et al. Immunomodulatory effect of red onion (Allium cepa Linn) scale extract on experimentally induced atypical prostatic hyperplasia in Wistar rats. Mediators of Inflammation 2014; 2014: 640746. [CrossRef]

134. Im K, Lee JY, Byeon H, Hwang KW, Kang W, Whang WK, et al. In Vitro antioxidative and anti-inflammatory activities of the ethanol extract of eggplant (Solanum melongena) stalks in macrophage RAW 264.7 cells. Food and Agricultural Immunology 2016; 27(6): 758-71. [CrossRef]

135. Cherng JM, Chiang W, LC. C. Immunomodulatory activities of common vegetables and spices of Umbelliferae and its related coumarins and flavonoids. Food Chemistry 2008; 106(3): 944-50. [CrossRef]

136. Skinner MA, Bentley-Hewitt K, Rosendale D, Naoko S, Pernthaner A. Effects of kiwifruit on innate and adaptive immunity and symptoms of upper respiratory tract infections. Advances in Food and Nutrition Research 2013; 68: 301-20. [CrossRef]

137. Iwasawa $H$, Morita $E$, Ueda $H, M Y$. Influence of kiwi fruit on immunity and its anti-oxidant effects in mice. Food Science and Technology Research 2010(16): 135-42. [CrossRef]

138. Tezuka H, Imai S. Immunomodulatory Effects of Soybeans and Processed Soy Food Compounds. Recent Patents on Food, Nutrition \& Agriculture 2015; 7(2): 92-9. [CrossRef]

139. Yamazaki K, Murray JA, Kita H. Innate immunomodulatory effects of cereal grains through induction of IL-10. The Journal of Allergy and Clinical Immunology 2008; 121(1): 172-8 e3. [CrossRef] 
140. Ye M, Liu JK, Lu ZX, Zhao Y, Liu SF, Li LL, et al. Grifolin, a potential antitumor natural product from the mushroom Albatrellus confluens, inhibits tumor cell growth by inducing apoptosis in vitro. FEBS Letters 2005; 579(16): 3437-43. [CrossRef]

141. Rahayu RP, Prasetyo RA, Purwanto DA, Kresnoadi U, Iskandar RPD, Rubianto M. The immunomodulatory effect of green tea (Camellia sinensis) leaves extract on immunocompromised Wistar rats infected by Candida albicans. Veterinary World 2018; 11(6): 765-70. [CrossRef]
142. Surjushe A, Vasani R, Saple DG. Aloe vera: a short review. Indian Journal of Dermatology 2008; 53(4): 163-6. [CrossRef]

143. Kim HS, Kacew S, Lee BM. In vitro chemopreventive effects of plant polysaccharides (Aloe barbadensis miller, Lentinus edodes, Ganoderma lucidum and Coriolus versicolor). Carcinogenesis 1999; 20(8): 1637-40. [CrossRef] 